\title{
Lessons in Leadership: Julius Caesar, Niccolo Machiavelli, and Napoleon Bonaparte
}

\author{
Kelly Dale Baird \\ Loyola University Chicago
}

Follow this and additional works at: https://ecommons.luc.edu/luc_diss

Part of the Education Commons

\section{Recommended Citation}

Baird, Kelly Dale, "Lessons in Leadership: Julius Caesar, Niccolo Machiavelli, and Napoleon Bonaparte" (1996). Dissertations. 3623.

https://ecommons.luc.edu/luc_diss/3623

This Dissertation is brought to you for free and open access by the Theses and Dissertations at Loyola eCommons. It has been accepted for inclusion in Dissertations by an authorized administrator of Loyola eCommons. For more information, please contact ecommons@luc.edu. (c) (i) $(9)$

This work is licensed under a Creative Commons Attribution-Noncommercial-No Derivative Works 3.0 License. Copyright @ 1996 Kelly Dale Baird 


\title{
LOYOLA UNIVERSITY CHICAGO
}

LESSONS IN LEADERSHIP: JULIUS CAESAR, NICCOLO MACHIAVELLI, AND NAPOLEON BONAPARTE

A DISSERTATION SUBMITTED TO THE FACULTY OF THE GRADUATE SCHOOL IN CANDIDACY FOR THE DEGREE OF DOCTOR OF PHILOSOPHY

\author{
DEPARTMENT OF \\ EDUCATIONAL LEADERSHIP AND POLICY STUDIES
}

BY

KELLY BAIRD

CHICAGO, ILLINOIS

MAY, 1996 
CC Copyright by Kelly D. Baird, 1996

All rights reserved. 


\section{ACKNOWLEDGMENTS}

I wish to extend my appreciation to all of my family, friends, and colleagues who were so instrumental in the development of this dissertation. I thank Dr. Mike Boyle for his countless hours of editing, Mae Goergen for putting together the final product, Dr. Robert Bunt for his expert advice, Dr. Janis Fine for her encouragement and direction, and most importantly to my wife Debbie. Without the love and support of my wife, I would never have been able to complete the doctoral process. Thank you to all. 


\section{ABSTRACT}

The purpose of this study was to demonstrate that there are examples in the history of western civilization of leaders who have embraced situational leadership. In addition, the selected leaders were viewed through the lens of situational ethics in order to analyze the impact that ethics had on their leadership style.

This dissertation followed the prescribed format of a literary analysis using documentary research methodology. Source material was used to gather evidence to support or reject the thesis that the leadership styles of Caesar, Machiavelli, and Bonaparte closely resembled the leadership profile found in Hersey and Blanchard's Model of Situational Leadership. The behavior of each leader was also examined in relation to Weber's Concept of Two Ethics.

The focus of this study was a comparative analysis of these three leaders, examining their relationship to each other and a description of the changes that occurred over time in each leader's situational leadership profile.

From the evidence, it was determined that only Caesar and Machiavelli embraced Hersey and Blanchard's Model of Situational Leadership because they altered their leadership style based on the readiness level of their followers. Napoleon did not. He only exhibited one form of leadership style. In addition, from the results of the study, it was determined that each 
leader exhibited what Max Weber termed the "Ethic of Ultimate End". Their actions were guided by an ultimate end. The daily application of their leadership style was their "ethic of responsibility".

Hersey and Blanchard's Model of Situational Leadership is the ethic of responsibility. The model is the daily application of leadership necessary to achieve an ultimate end. This framework was exhibited by Caesar and Machiavelli and, to a lesser degree, by Bonaparte. 


\section{TABLE OF CONTENTS}

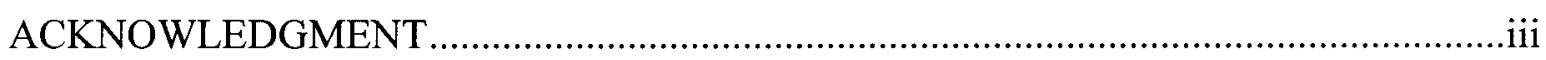

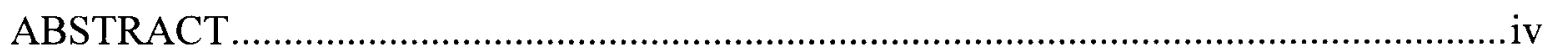

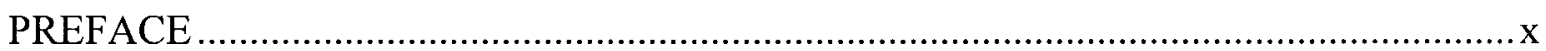

Chapter

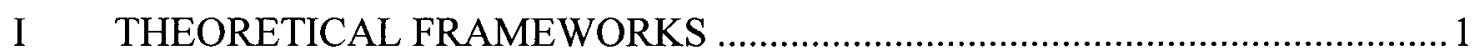

Description of the Model of Situational Leadership .......................................... 1

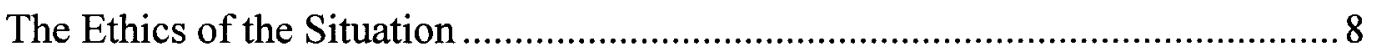

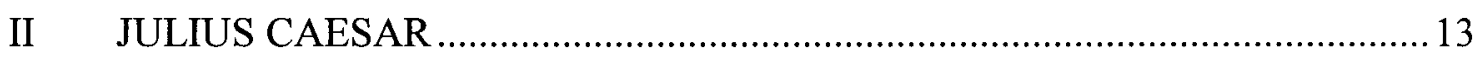

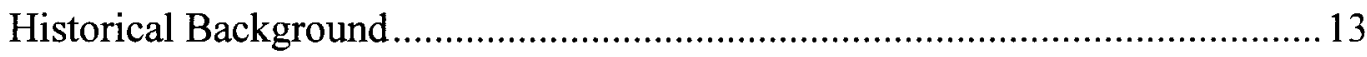

Writings of Julius Caesar ........................................................................ 18

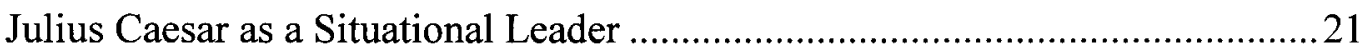

Julius Caesar and the Ethics of the Situation .................................................... 32

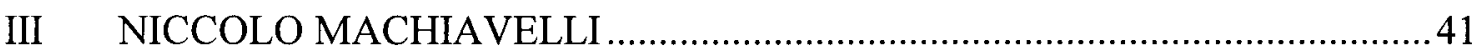

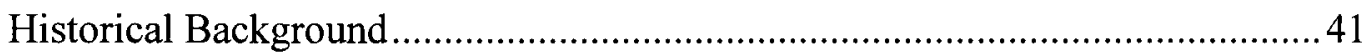

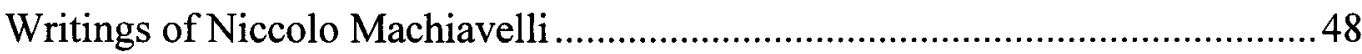

Niccolo Machiavelli as a Situational Leader..................................................52 
Niccolo Machiavelli and the Ethics of the Situation 60

IV NAPOLEON BONAPARTE 69

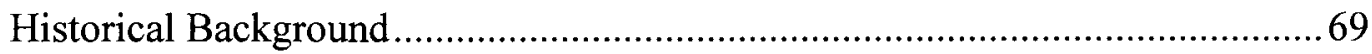

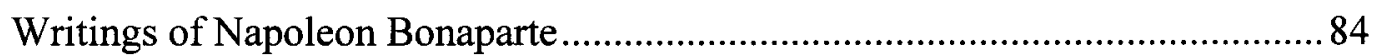

Napoleon Bonaparte as a Situational Leader..................................................86

Napoleon Bonaparte and the Ethics of the Situation.........................................93

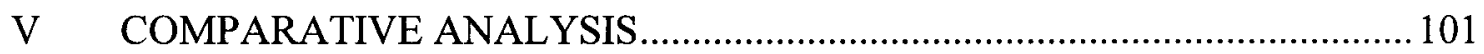

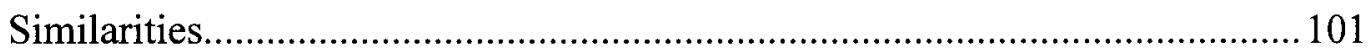

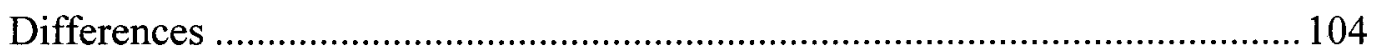

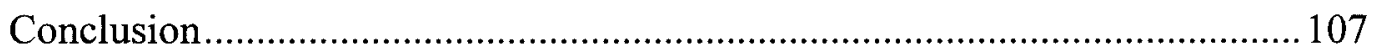

Implications for Educational Leaders Today ............................................ 110

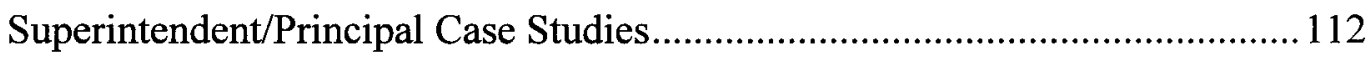

Situation A - Administrators Solving the Problems of Practice......................... 112

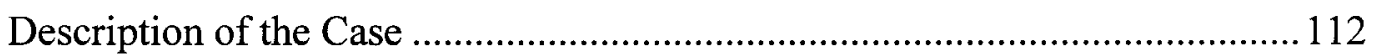

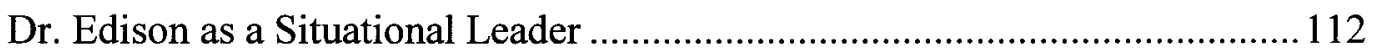

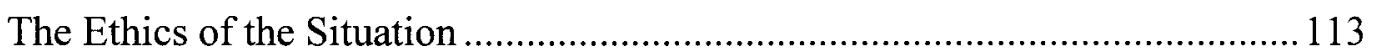

Situation B - Administrators Solving the Problems of Practice ........................ 113

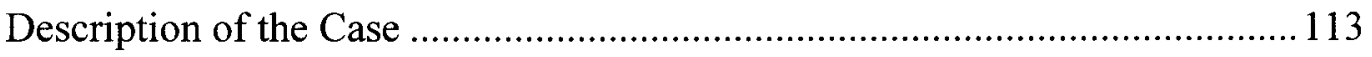

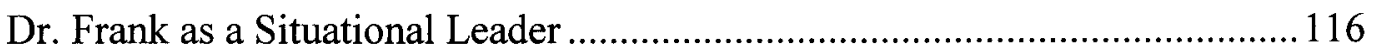

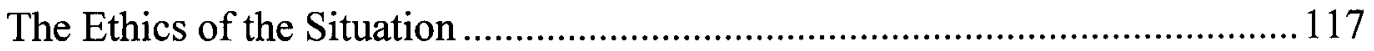


Situation C - Administrators Solving the Problems of Practice.

Description of the Case

The Principal as a Situational Leader ............................................................ 118

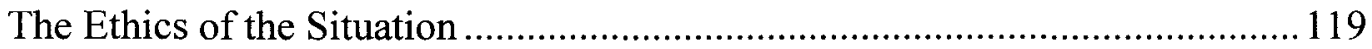

Situation D - Educational Administration A Collection of Case Studies.......... 119

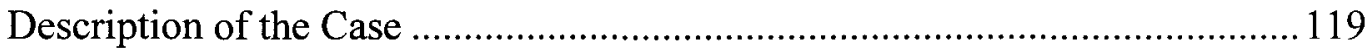

The Principal as a Situational Leader ............................................................ 120

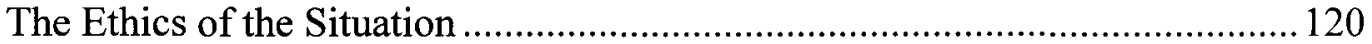

Comparison of Julius Caesar, Niccolo Machiavelli, and Napoleon Bonaparte

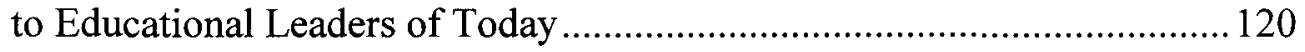

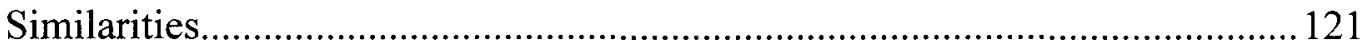

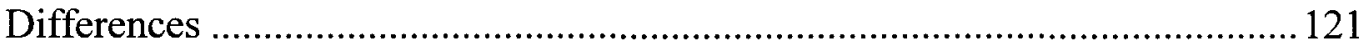

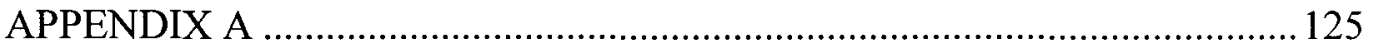

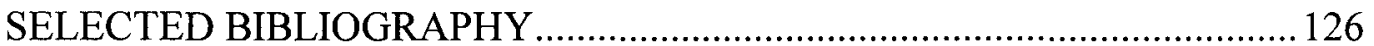

VITA 


\section{LIST OF FIGURES}

Figure

1. Julius Caesar - Leadership Styles and Readiness Level of Followers.....................25

2. Niccolo Machiavelli - Leadership Styles and Readiness Level of Followers ..........54

3. Napoleon Bonaparte - Leadership Styles and Readiness Level of Followers ..........88

4. Case Studies Education Leaders Today - Leadership Styles

and Readiness Level of Followers 114 


\section{PREFACE}

Throughout the history of western civilization, the leader and leadership has been analyzed by writers and philosophers. Questions such as 1)what is a leader; 2)how is a leader different from a follower; 3)what effect does the environment of different situations have on leadership; and 4) how ethics impact changing situations have been addressed in many different ways.

Paul Hersey and Kenneth Blanchard have recently addressed the question of leadership. They have developed a model to help leaders develop an understanding of the relationship between an effective style of leadership and the level of readiness of their followers. This understanding is built upon a knowledge of the interplay among 1)the amount of guidance and direction (task behavior) a leader gives; 2) the amount of socioemotional support (relationship behavior) a leader provides; and 3)the readiness level that followers exhibit in performing a specific task, function or objective. This correlation forms Hersey and Blanchard's Model of Situational Leadership.

Is The Model of Situational Leadership new? Have there been examples of leaders embodying these leadership characteristics throughout the ages?

This dissertation will attempt to demonstrate that there are examples in the history of western civilization of leaders who have embraced situational leadership. Through primary and secondary source material written by and about selected leaders, this 
dissertation will analyze leadership style and relate that style to a profile of situational leadership developed in Hersey and Blanchard's Model. In addition, the selected leaders will be viewed through the lens of situational ethics.

The leaders from the history of western civilization analyzed in this study were Julius Caesar, Niccolo Machiavelli, and Napoleon Bonaparte. These leaders were pivotal figures from Classical Rome, The Italian Renaissance, and Imperial France.

Julius Caesar was a careful observer of the political and military situations surrounding him. He was able to accommodate and adapt based on the ebb and flow of both changing military and political situations. His adaptability to these situations allowed Caesar to capture the leadership of the most powerful state of the classical world.

Niccolo Machiavelli rose to prominence in a unique period in the history of western civilization. Europe was emerging from the shadows of the Dark and Middle Ages. The church was losing its dominance to be replaced by the concept of individualism first evidenced in Ancient Greece. The individual, not God, was becoming the measure of all things in this era known as the Renaissance.

Machiavelli was a landowner who spent his day overseeing the daily operations of his properties. At night, once he crossed the threshold of his study, a transformation occurred. As he pored over his beloved works from Ancient Greece and Rome, he became one with Plato, Aristotle, Plutarch, Cicero, etc. From this framework, Machiavelli began his works on practical advice for leaders of his time. From his background in classical history, Machiavelli developed his famous phrase for political survival. He said 
that it was imperative that leaders must know "when to be as cunning as the fox and when to be courageous as the lion." Different situations called for the application of different ethics in order to maintain political or military survival. According to Max Weber: From a sociological point of view an "ethical standard is one to which men attribute a certain type of value and which, by virtue of this belief, they treat as a valid norm governing their action. In this sense it can be spoken of as defining what is ethically good in the same way that action which is called beautiful is measured by esthetic standards. ${ }^{i}$

Different situations call for distinct norms to govern actions. Separate actions are viewed as being "ethically" correct dependent upon the situation. The norms which served as standards for Caesar, Machiavelli, and Napoleon changed depending on the situation.

No one knows truly what the vision of Napoleon Bonaparte was. While he rose to power in the twilight of the Age of Reason, with its philosophers famous for their clear, sequential logic, Napoleon did not demonstrate the order of this decision making. He was a man whose thoughts led directly to action. His thoughts were not the germ of other thoughts but rather his thoughts led directly to marches, battles and campaigns. As a man of action, Napoleon was constantly confronted with changing situations. While he was in Egypt, the French government sought to remove him from power. While massing troops and ships for the invasion of England, a new alliance of Austria and Russia forced him to alter his invasion plans and march on Central Europe. After defeating every Russian 
Army sent against him, Napoleon was forced to retreat from Moscow when confronted with drastically altered circumstances. Changing situations led to changing ethics which led to actions based on new opportunities.

Napoleon fought as no man had fought before him. His radical thoughts and tactics were the results of altered situations which he faced. His success, while it lasted, was based on an adaptability to the changing situations and ethics of those situations.

The focus of this study will be a comparative analysis of the three leaders, examining their relationship to each other and a description of the changes that occurred over time in each leaders' situational leadership profile. Caesar, Machiavelli, and Bonaparte each found themselves in situations which called for different actions dependent on those situations. Through the use of a situational leadership profile, examined against some lessons of the past, today's leaders will be provided with a model that can guide their leadership style in influencing the behavior of others. A bridge is made to the past for educational leaders of today by utilizing superintendent and principal case studies which exhibit leadership characteristics similar to Hersey and Blanchard's model.

This dissertation follows the prescribed format of a literary analysis using documentary research methodology. Source material was used to gather evidence to support or reject the thesis that the leadership styles of Caesar, Machiavelli, and Bonaparte closely resembled the leadership profile found in Hersey and Blanchard's Model of Situational Leadership. 
From the analysis of Hersey and Blanchard's Model of Situational Leadership, a leadership style profile was developed. The behavior of these three leaders was also examined in terms of the ethics of changing situations.

Primary source data will be collected from texts written by the leaders. The primary source material will include Caesar's The War Commentaries of Caesar, Machiavelli's The Prince, The Discourses, and The Art of War, and excerpts from Napoleon's writing in The Mind of Napoleon. Secondary source material will include commentaries on Caesar, Machiavelli, and Bonaparte.

Chapter one of this dissertation will be a description of Hersey and Blanchard's Model of Situational Leadership and a description of Max Weber's concept of two ethics. The profile of situational leadership will be examined in relationship to the ethics of changing situations.

Chapters two, three, and four will focus on Julius Caesar, Niccolo Machiavelli, and Napoleon Bonaparte respectively. Each chapter describes the historical context of the primary and secondary situations that confronted that leader, and analyze the relationship between the leader's leadership style and the profile of a situational leader.

In the final chapter, a comparative analysis of the Model of Situational Leadership as evidenced in the styles of Caesar, Machiavelli, and Bonaparte for today's leaders will be discussed. While all three leaders were from the military/political paradigm, implications for educational leaders of today will be given. In addition, examples of educational leadership style characteristics will be diagrammed to contribute to the 
understanding of how the lessons of the past apply to situations for educational leaders today. 


\section{PREFACE NOTES}

${ }^{i}$ Max Weber, Economy and Society, ed. Guenther Roth and Claus Wittich (New York: Bedminster Press, 1968), 36. 


\section{CHAPTER I}

\section{THEORETICAL FRAMEWORKS}

\section{DESCRIPTION OF THE MODEL OF SITUATIONAL LEADERSHIP}

This chapter outlines Hersey and Blanchard's Model of Situational Leadership, the conceptual framework through which the leadership styles of Julius Caesar, Niccolo Machiavelli, and Napoleon Bonaparte are analyzed. Max Weber's Concept of Two Ethics is utilized as an additional lens through which the style of the above leaders is studied.

One of the major outcomes of the Hersey and Blanchard's work in leadership has been the creation of a pragmatic model that can be used by managers to make decisions in diverse situations faced on a day to day basis. Hersey and Blanchard's Situational Leadership model is the culmination of earlier leadership models that classified leadership behavior based on the identification of two behaviors: task and relationship.

Task behavior is defined as the extent to which the leader engages in spelling out the duties and responsibilities of an individual or group. These behaviors include telling people what to do, how to do it, when to do it, where to do it, and who is to do it.

Relationship behavior is defined as the extent to which the leader engages in two-way or multi-way communications. These behaviors include listening, facilitating, and supportive behaviors. ${ }^{1}$

Leadership is influencing behavior. Warren Bennis notes:

"On Becoming a Leader" is based on the assumption that leaders are people who are able to express themselves fully. By this I mean that they know who they are, what their strengths and weaknesses are, and how to 
fully deploy their strengths and compensate for their weaknesses. They also know what they want, why they want it, and how to communicate what they want to others, in order to gain their cooperation and support. ${ }^{2}$

Gaining the cooperation and support of a group of followers is influencing their behavior. Warren Bennis examines the concept of influence and states, "Leaders manage attention through a compelling vision that brings others to a place they have not been before." ${ }^{3}$ Once again the leader influences the behavior of others.

Tom Peters defines leadership as the following, "Leadership means vision, cheerleading, enthusiasm, love, trust, verve, passion, obsession, consistency, the use of symbols, pay attention as illustrated by the content of one's calendar, out-and-out drama (and the management thereof), creating heroes at all levels, coaching, effectively wandering around, and numerous other things." ${ }^{, 4}$ All lead toward influencing the behavior of others.

While leadership can be defined as influencing the behavior of others, this influence can be manifested in different ways. In Francis Griffith's book on administrative theory, Robert Tannenbaum and Warren H. Schmidt state:

Many discussions on leadership give the impression that there are only two ways of running an enterprise: the democratic, participatory approach and the authoritarian, one-man method. No such conflict should exist. There is a whole spectrum of leadership attitudes, and different approaches are appropriate to different situations. ${ }^{5}$

Leadership means influencing people and there is no one way for leaders to influence people in all situations. Effective leaders have an arsenal of leadership styles to apply to different situations. 
The Model of Situational Leadership, an arsenal of leadership styles for the effective leader, is based on the interplay among:

1. The amount of guidance and direction (task behavior) a leader gives;

2. the amount of socio-emotional support (relationship behavior) a leader provides; and

3. the readiness level that followers exhibit in performing a specific task, function, or objective. ${ }^{6}$

The emphasis in Situational Leadership is the behavior of a leader in relation to followers. Followers are vital because without them a leader cannot exhibit influencing behavior.

Of primary importance in understanding The Model of Situational Leadership is the understanding or conceptualization of followers' readiness:

"Readiness is defined as the extent to which a follower has the ability and willingness to accomplish a specific task. People tend to be at different levels of readiness depending on the task that they are being asked to do. Readiness is how ready a person is to perform a particular task."7

The concept of readiness is comprised of two major components:

1. Ability is the knowledge, experience, and skill that an individual or group brings to a particular task or activity.

2. Willingness is the extent of which an individual or group has the confidence, commitment, and motivation to accomplish a specific task. $^{8}$

When analyzing the ability level of someone, it is important to be task specific.

The focus must be on the outcome desired and in analyzing the ability of followers in respect to that outcome.

People are not necessarily unwilling if they cannot perform a specific task. It may be that they have never done that task before and are therefore, insecure. 
Even though the concepts of ability and willingness are different, it is important to remember that they are an interchangeable system. A change in one will affect the whole. What followers bring to a situation regarding willingness will affect the use of their ability. In a military situation, if soldiers are asked to advance under heavy fire and they are unwilling and/or unable to do so, then the leader may have to simply tell them to advance. In this situation the leader would not ask his followers, the soldiers, to participate in a decision making process. He would not try to sell them on the idea nor would he delegate authority to the troops with the hopes that they would attack. Instead, he would simply tell them to advance. If, however, the troops are more willing or able to advance, the leader may share some of the responsibility of leadership by allowing them to participate in plotting strategy.

Followers may have different levels of readiness dependent upon the specific task. The follower readiness continuum can be divided into four levels: Low (R1); Low to Moderate (R2), Moderate to High (R3), and High (R4). Each level symbolizes a different combination of follower ability and willingness. (See Appendix A, page 125.)

1. Readiness Level One (R1)

Unable and unwilling

The follower is unable and lacks commitment and motivation, or

Unable and insecure

The follower is unable and lacks confidence.

2. Readiness Level Two (R2)

Unable but willing

The follower lacks ability, but is motivated and making an effort. or

Unable but confident

The follower lacks ability, but is confident as long as the leader is there 
to provide guidance.

3. Readiness Level Three (R3)

Able but unwilling

The follower has the ability to perform the task, but is not willing to use that ability.

or

Able but insecure

The follower has the ability to perform the task, but is unsure or apprehensive about doing it alone.

4. Readiness Level Four (R4)

Able and willing

The follower has the ability to perform and is committed to use the task.

or

Able and Confident

The follower has the ability to perform and is confident about doing it. $^{9}$

The appropriate leadership style used by a leader in any given situation is based

on the four levels of readiness. This involves a combination of task behavior (giving

direction) and relationship behavior (providing support).

"Match of Readiness Level 1 with Leadership Style 1-Telling: For a follower or group that is at Readiness Level 1 for a specific task, it is appropriate to provide high amounts of guidance but little supportive behavior. This style is appropriate when an individual or group is low in ability and willingness and needs direction.

Match of Readiness Level 2 with Leadership Style 2-Selling: The next range of readiness is Readiness Level 2 . This is an individual or group that is still unable to perform the given task, but they are trying. They are willing or confident. It is different from telling in that the leader is not only providing guidance, but is also providing the opportunity for dialogue and for clarification in order to help the person accept psychologically what the leader wants. At this level, dialogue is encouraged (between the leader and follower).

Match of Readiness Level 3 with Leadership Style 3-Participating: Readiness Level 3 would include a person or group that is capable of performing the task, but who has not had an opportunity to gain confidence in doing it independently. Readiness Level 3 could be a person or group that is able and willing, but for one reason or another is not 
motivated. At this level, the leader's major responsibility is to provide encouragement and encourage communication.

Match of Readiness Level 4 with Leadership Style 4-Delegating:

Readiness Level 4 is where the individual or group is both ready and willing, or ready and confident. It is unnecessary to provide direction about where, what, when, or how because the followers already have the ability. The appropriate style involves giving them the ball and letting them run with it. It is important to give these followers an opportunity to take responsibility and implement on their own."10

It is important to note that the unwillingness of followers in Readiness Level 1 matches up with the leadership style of Telling. The followers who are unable but willing and confident, Readiness Level 2, match well with the leadership style of Selling. Readiness Level 3 followers who are able but unwilling match up with the Participating Leadership Style. Finally, followers who are able/competent and willing match up effectively with the low relationship/low task behavior of the Delegating style of leadership.

The leader who is successful at applying the Model of Situational Leadership will determine the readiness level of the followers and then adjust his/her behavior as the model prescribes:

Situational leadership contends strong direction (task behavior) with followers with low readiness is appropriate if they are to become productive. Similarly, it suggests that an increase in readiness on the part of people who are somewhat unready should be rewarded by increased positive reinforcement and socio-emotional support (relationship behavior). Finally, as followers reach high levels of readiness, the leaders should respond by not only continuing to decrease control over their activities, but also by continuing to decrease relationship behavior as well. With people with high readiness, the need for socio-emotional support is no longer as important as the need for greater freedom. At this stage, one of the ways leaders can prove their confidence and trust in these people is to leave them more and more on their own. It is not that there is less 
mutual trust and friendship between leader and follower - in fact, there is more - but it takes less supportive behavior on the leaders part to prove this to them. ${ }^{11}$

Hersey and Blanchard comment on the examination of the elements of readiness.

These observations are important for leaders as they begin to analyze the readiness level of their followers.

First, Hersey and Blanchard note that based on David C. McClelland's study:

Achievement-motivated people have certain characteristics in common, including the capacity to set high but obtainable goals, the concern for personal achievement rather than the rewards of success, and the desire for task-relevant feedback (how well am I doing?) rather than attitudinal feedback (how well do you like me?) ${ }^{12}$

Second, Hersey and Blanchard assert that there is no conceptual distinction between education and/or experience. One can gain task-relevant readiness through education or experience or a combination of both. The only difference between the two is that when they are talking about education, they are referring to formal classroom experiences, and experience involves what is learned on one's own or on the job. ${ }^{13}$

Third, Hersey and Blanchard argue that education and/or experience affects ability and that achievement motivation affects willingness. As a result, they are suggesting that their concept of readiness consists of two dimensions: ability and willingness. ${ }^{14}$

The two terms used in the examination of leadership and followers are "ability" (job readiness) and "willingness" (psychological readiness).

Ability (job readiness) is related to the ability to do something. It has to do with knowledge and demonstrated skill. Individuals with high job readiness in a particular area 
have the knowledge, skill, and experience to perform certain tasks without direction from others.

Willingness (psychological readiness) is related to the acceptance or motivation, to do something. It deals with confidence and competence. Individuals who have high psychological readiness in a particular area or responsibility think that responsibility is important and have self-confidence about themselves in that aspect of their job. They do not need encouragement to get them to do things in that situation. ${ }^{15}$

Hersey and Blanchard's Model of Situational Leadership is an effective framework that can be used by leaders in a proactive manner. In applying the model, leaders define the readiness level of the followers and match their leadership style to the readiness level of the follower. When a correct match is made, the task will be accomplished and the follower will progress towards a greater level of readiness. This in conjunction with influencing the behavior of others, is the goal of leadership.

Hersey and Blanchard have developed a model of leadership style that is meant to build a repertoire of styles that can be applied by leaders in influencing others to accomplish specific tasks. Leaders must apply different styles in different situations in order to effectively influence behavior. Hence, their leadership style is based on the situation.

\section{THE ETHICS OF THE SITUATION}

Hersey and Blanchard's model can not be viewed in a vacuum. The ethics of the situation should be analyzed to fully comprehend all of the ramifications of decisions that 
are made when influencing the behavior of others.

In "Politics as a Vocation" Max Weber examines two types of ethics.

We must be clear about the fact that all ethically oriented conduct may be guided by one of two fundamentally differing and irreconcilably opposed maxims: Conduct can be oriented to an "ethic of ultimate ends" or to an "ethic of responsibility." This is not to say that an ethic of ultimate ends is identical with irresponsibility, or that an ethic of responsibility is identical with unprincipled opportunism. Naturally nobody says that. However, there is an abysmal contrast between conduct that follows the ethic of ultimate ends - that is in religious terms, "The Christian does rightly and leave the results with the Lord" - and conduct that follows the maxim of an ethic of responsibility, in which case one has to give an account of the foreseeable results of one's action. ${ }^{16}$

The ethic of ultimate ends analyzes a person's behavior by the degree of their adherence to good ends or high purposes. The ethic of responsibility, however, measures actions by the person's ability to use a calculating approach in making choices. Those choices are not made based on one value or interest but rather on many. The consequences are all important not just a lofty intent.

The ethic of responsibility, when followed by a leader, allows opportunistic and self-serving behavior because responsibility can be expanded to authorize opportunism. Leaders adhering to the ethic of responsibility can end up serving only their narrow, short-term interests. These leaders act with an attitude towards being responsible to their families or to some other relatively narrow group.

Burns points out that Weber over simplified matters. He notes that: Most leaders and followers shift back and forth from specific, self-involved values to broader, publicinvolved ones. ${ }^{17}$ 
The ethic of responsibility can be viewed, according to Burns, to be the day to day implementation of the "ethic of ultimate ends" to multi-layered situations. The ethic of responsibility becomes the practical application of the loftier ethic of ultimate ends.

When leadership style and follower readiness are analyzed to determine whether or not behavior was influenced, one must examine the goals of the leader. The goals are viewed through the two ethics of responsibility and ultimate ends.

When defining effectiveness, one must determine if a leader is acting in a selfindulgent manner in influencing behavior or with higher ends in mind.

When making a decision to influence others, the leader needs to analyze the readiness level of the followers as well as the ethics of the situation. The leader needs to be cognizant of his/her goals and how they relate to the ethics of the situation.

In this dissertation, the Situational Leadership Model is used to analyze the behaviors of three leaders from the history of western civilization. A careful analysis of the behavior and actions of Julius Caesar, Niccolo Machiavelli, and Napoleon Bonaparte is used to identify their leadership style ( $\mathrm{S} 1, \mathrm{~S} 2, \mathrm{~S} 3, \mathrm{~S} 4)$. The readiness level (R1, R2, R3, R4) of their followers is also defined as part of this analysis. The examination of the leadership styles used by three historical figures, with their followers at a particular readiness level in conjunction with the ethics of the situation, offers insight into why the leaders were successful in some situations and failures in others. 


\section{CHAPTER I NOTES}

${ }^{1}$ Paul Hersey and Kenneth H. Blanchard, Management of Organizational Behavior (Englewood Cliffs, N. J.: Prentice Hall, 1993), 184-200.

${ }^{2}$ Warren Bennis, On Becoming a Leader (Reading, Massachusetts: AddisonWesley Publishing Company, Inc., 1989), 3.

${ }^{3}$ Warren Bennis, Why Leaders Can't Lead (San Francisco: Jossey-Bass Publishers, 1989), 19.

${ }^{4}$ Tom Peters and Nancy Austin, A Passion for Excellence (New York: Random House, 1985), 5-6.

${ }^{5}$ Francis Griffith, Administrative Theory in Education: Text and Readings

(Midland, Michigan: Pendell Publishing Company, 1979), 166.

${ }^{6}$ Hersey and Blanchard, 184.

${ }^{7}$ Ibid., 189.

${ }^{8}$ Ibid., 190.

${ }^{9}$ Ibid., 190.

${ }^{10}$ Ibid., 200.

${ }^{11}$ Ibid., 196-197.

${ }^{12}$ Ibid., 200.

${ }^{13}$ Ibid., 200.

${ }^{14}$ Ibid., 200. 
${ }^{15}$ Ibid., 200.

${ }^{16}$ Max Weber, Politics as a Vocation, trans. H. H. Gerth and C. Wright Mills (Philadelphia: Fortress Press, 1965), 46-47.

${ }^{17}$ James MacGregor Burns, Leadership (New York: Harper Torchbooks, 1987), 45. 


\section{CHAPTER II}

\section{JULIUS CAESAR}

\section{HISTORICAL BACKGROUND}

To truly understand Julius Caesar, the researcher must analyze the historic context of his era. To examine Caesar in this manner, the lens of a socio-economic, political and military perspective will be utilized.

Rome had fought a series of wars with Carthage, a sea power situated on the north coast of Africa, from 264 - $146 \mathrm{BC}$. This long struggle resulted in tremendous human and material devastation in Italy as well as Carthage. Rome prevailed against Carthage and became a world power. Rome now found itself in the center of trade routes from the East which had previously been monopolized by Carthage. With the final destruction of Carthage, Rome was poised to assume a world leadership role. "However, the long war with Hannibal created within Italy an economic vacuum into which the outpouring-of wealth from the East were sucked." With Carthage removed from the scene, the riches that had filled the coffers of Carthaginian traders now went to Rome.

The upper class of Rome received benefits from their victories. "Much land was on the market and slaves were abundant." Many of the farmers of the Italian peninsula were either killed or forced off their land during the constant fighting and 
slaves were obtained with each new conquest of the Roman Army.

By Caesar's time, the republic was beginning to crumble. Tensions between the patricians and the plebeians, changes in the economic conditions, and rapid military conquests all took a toll. Arthur Boak and William Sinnigen state,

"The governing circles had proven to be incapable of improving situations and had completely lost the power of preserving peace. Radical reforms were imperative and could be effected only with superior force."3

The political struggles and the military victories had a tremendous impact on the already tense social conditions. Flaurus writes, "The resources and wealth acquired by conquest spoiled the morals of the age and ruined the state." ${ }^{\prime 4}$ Rome had been a moralistic society. Arthur Kahn points out in his text on Caesar, "Roman children were made conscious of the uniqueness of their heritage and of their historical mission to bring peace and order to the world." As Kahn also notes,

Caesar's mother indoctrinated him in the typical Roman virtues:

1. Rugged endurance.

2. Frugal manner of life.

3. Plain and simple use of material possessions.

4. Religion.

5. Upright dealing and great care in avoiding wrongdoing in relations with all men. ${ }^{6}$

These principles were what Roman Society had been built upon. But due to pressures from many different directions including economic, society was changing.

The political structure of Rome had undergone an evolution from its founding in $753 \mathrm{BC}$ until the time of Caesar's era - around $58 \mathrm{BC}$.

Originally, Rome had been a monarchy with citizen assemblies and a Senate comprised of the heads of the three clans which were joined to form 
Latium. Eventually, around $509 \mathrm{BC}$ the last Etruscan monarch was overthrown and a republic was formed. The leaders of the Roman Republic came from one of two classes, the patricians, rich land owning Romans, or the plebeians, craftsmen and traders:

The families of aristocrats who governed the early Republic were patricians. Through the fifth and fourth century BC, plebeians fought a long but successful struggle to abolish patrician privilege. ${ }^{?}$

Originally senators, who served for life, were patricians. The Senate controlled the assemblies that elected the consuls, who served for one year. Therefore, the patricians controlled the government of the early republic. Eventually, the plebeians formed their own assembly and the office of tribune developed. Through this office, the plebeians in the later stages of the republic, began to share power with the patricians. However, as R. H. Barrows noted, "The history of the republic from the end of the Punic Wars to Caesar was the story of conflict and maneuver between patricians and plebeians." ${ }^{98}$ No matter how successful the plebeians were at wresting power from the patricians, this long struggle caused social and political tensions that were evident even in Caesar's day. In the second century BC, the Gracchus brothers came to power as tribunes. As described by Barrows,

"Tiberius Gracchus challenged the Roman Constitution. He developed programs which attempted to cure the depopulation of the countryside and the decline of agriculture." 9

Once the Gracchus brothers and their followers were deposed Rome had changed. Barrows points out that, "The age that followed the Gracchus brothers was the age of great individuals seeking to alter the machine of government as they adapted to new 
stresses and yet preserving as many of the old components as possible." ${ }^{\prime 10}$ Caesar came to power during the "Age of Great Individuals." Also in power at the same time were Crassus and Pompey. Pompey and Crassus were rivals for mastery of Rome as Caesar came of age. As William Hale notes,

"Caesar mediated a truce between Pompey and Crassus in 60 BC. He brought the two statesmen together to form the First Triumvirate which marked Caesar's bid for power." 11

The die was cast. Eventually Crassus died which left only Pompey and Caesar in a mutual bid for supremacy. Plutarch stated, "Caesar had long ago resolved upon the overthrow of Pompey, as had Pompey for that matter upon him." 12 They would soon be at each others throats. The Roman political situation was very fluid. It was a ripe occasion for a situational leader to promote his rule.

Caesar began his campaigns in Gaul as a means to an end. The goal was to rule the Roman World. Fuller acknowledged, “Although the conquest of Gaul was the greatest of Caesar's achievements, at the time it was little more than a stepping stone in his struggle for power, and as we have seen, that was why he, at the close of each campaigning season would winter in Cisalpine Gaul in order to retain touch with political events." 13

In early Rome, only land owning citizens could serve in the army. After the wars, the legionnaires would return to their farms. As men left the land for war, to seek opportunities in the city, or were killed, the land would be taken over by the rich. Eventually, the army organized around basic units called centuries (100 men) and legions (5,000 men), became a professional standing force and not one formed only in times of 
emergency. "By 107 BC Marius, Julius Caesar's uncle, brought about a change in the attitude of the army by creating a long service body trained to meet the menace of the Germans." ${ }^{14}$ No longer were the Roman legions filled with men who were land owning farmers simply performing their patriotic duty.

The standing, professional army was able to improve its tactics through continued service.

In brief, against their like, as well as against barbaric warriors, the techniques of legionary battles may be summarized as follows:

1. To engage the minimum number of combatants necessary to wage the initial fight.

2. To support the fighting front with reliefs and replacements stationed immediately in rear of it.

3. To hold a reserve well outside the zone of demoralization, in order to feed the supports when required, or to clinch victory by a final assault with fresh troops. ${ }^{15}$

Through the use of these tactics and in conjunction with Roman discipline and order, the legions evolved into the most feared military unit in the ancient world. This army was an extension of the political system and the generals also became part of the political framework. With his military background and political skills, Caesar was at a stage of readiness to move to take control.

By Caesar's time, the legions owed their allegiance to their general who would lead them to victories which would produce land and slaves for them. They no longer stirred to action through patriotism to the state. The general and what he could bring to them became the driving force of the world's most fearsome military and political machine. 
Caesar went to Gaul in $58 \mathrm{BC}$. This was the first step in his bid for leadership. He knew how to achieve his goals both politically and militarily. In their description of Caesar, Arthur Boak and William Sinniger also state, "Although he was ruthless and cold-blooded in pursuing his ends, his personal charms enabled him to create a remarkable espirit de corps among his troops and evoked a corresponding loyalty and solidarity among his political adherents. ${ }^{, 16}$ Caesar was truly one of the great individuals of Ancient Rome. As a leader, he knew how to adjust his style based on both the changing situation and ethics.

\section{WRITINGS OF JULIUS CAESAR}

The War Commentaries of Caesar is the story of a man who rose to power through military prowess, toppled the republic, and began a dictatorship. As a result of his rise to power, if but only for a few brief years, Caesar became the master of the ancient world.

The text was written by Caesar and related the events of his military campaign from $58 \mathrm{BC}$ to $48 \mathrm{BC}$. The book is divided into two major sections, one describing the Gallic Wars and the second outlining the Roman Civil War.

Julius Caesar's goal was supreme power and his appointment as governor of the Roman Province in Gaul was a stepping stone in his ascent to power. The Roman Province was referred to as Cisalpine Gaul. The Gauls were predominantly of the Celtic race and, being true to the nature of the Celts, were involved in constant intertribal warfare.

These tribal wars revolved around many issues but primarily focused on land for expanding populations. Another cause for war was the periodic encroachment of 
Germanic tribes from across the Rhine River searching for more fertile land. As they pushed into Gaul, a chain reaction of Gallic migrations were set off by tribes along the Rhine pushing westward to escape the warlike and ferocious Germans. In addition, as the Gauls fought with one another, one of the tribes would occasionally invite German warriors to cross the Rhine to fight with them against their opponents. More often than not Germans, once experiencing the fertility of the Gallic lands, refused to leave when the fighting had ceased. Caesar as a military leader could exploit the situation of having a divided rather than united enemy.

Caesar's campaigns in Gaul began in the spring of $58 \mathrm{BC}$ when the Helvetii, who lived near Geneva, migrated westward, due to pressure from German tribes. Their path would have brought them directly through Caesar's province. To complicate matters further, Ariovistus, a German King whose tribe had already been living in Gaul, also took the offensive.

Caesar turned first on the Helvetii and defeated their army near the town of Bibracte. Next, he met the Germans under Ariovistus and routed them. Many Gallic tribes had now begun to seek out Caesar for protection.

In $55 \mathrm{BC}$ two more German tribes crossed the Rhine and initiated war with Gallic allies of Rome. Caesar chased the Germans all the way back to the Rhine and in ten days built a bridge, crossed over and fought the Germans on the east side of the Rhine, a feat unheard of at the time.

That same year, for reasons unexplained, Caesar crossed the channel and invaded Britain. He fought the Britons and returned to Gaul. The next year, he again went to 
Britain and fought Cassivelaunus, the King of the Britons. After defeating the Britons and collecting tribute, the Romans returned to Gaul.

Early in $52 \mathrm{BC}$ Vercingetorix, a Gallic leader, had managed to unite nearly all the Gallic tribes for one last bid for independence. Caesar won several victories against isolated armies of Gaul and then cornered Vercingetorix and 30,000 Gauls in the walled town of Alesia. Caesar had approximately the same number of men but shortly he found 250,000 Gallic warriors to his rear attempting to rescue Vercingetorix and his men.

Caesar's army built concentric circular fortifications all around Alesia so that Vercingetorix couldn't escape and the Gauls on the outside couldn't get in. After several weeks of constant fighting, the Gauls gave up. The Gauls outside of Alesia melted away in small bands and Vercingetorix surrendered himself to Caesar. Gaul was now firmly in the hands of Julius Caesar.

The second section of Caesar's commentaries describes the Civil War which pitted Julius Caesar against Pompey. While Caesar had been increasing the territory controlled by Rome, Pompey and his legions had remained in Italy, plotting against Caesar.

Civil strife was escalating rapidly in Rome while Caesar was fighting in Gaul. His term as governor in Gaul ended in $49 \mathrm{BC}$ and he couldn't run for the consulship until the Fall of that year. Pompey had won over the Senate and was trying to get Caesar put on trial or banished. The Senate demanded that Caesar dismiss his troops.

Caesar crossed the Rubicon River, entering Italy proper, in $49 \mathrm{BC}$. This was the beginning of the Civil War which placed Caesar and his legions against Pompey. 
Pompey crossed the Adriatic Sea and settled his legions in Brundisium. Caesar marched into Spain. After defeating one of Pompey's generals, all of Spain came over to Caesar.

Caesar now turned back to Pompey. By land and sea, Caesar's legions traveled to confront their foe. They fought and Caesar's vastly outnumbered army was repulsed. Pompey was reluctant to pursue this victory. Finally, he marched out to meet Caesar at Pharsalus. Pompey was defeated and fled to Egypt where he was killed by Pothinus, the vizier of the Egyptian King, Ptolemy XII. Caesar was now the sole ruler of the Roman world. Shortly thereafter Caesar fell to the knife of Brutus on the Ides of March. Thus ends the commentaries of Julius Caesar.

\section{JULIUS CAESAR AS A SITUATIONAL LEADER}

To determine the extent to which Julius Caesar exhibited leadership style characteristics which resembled the model presented by Hersey and Blanchard, the researcher must analyze the task behavior and relationship behavior displayed in the primary source of Julius Caesar. In addition, in accordance with the Model of Situational Leadership, the readiness level of the followers which is defined as how ready a person is to perform a specific task, must be studied, for a successful leader according to Hersey and Blanchard adopts his leadership style (task and relationship behavior) based on the "readiness" level which his followers exhibit on a specific task.

Situational leadership according Hersey and Blanchard is based on the interplay among 1) the amount of guidance and direction (task behavior) a leader gives; 2) the amount of socio-emotional support (relationship behavior) a leader provides; 3 ) the 
readiness level that followers exhibit in performing a specific task, function, or objective. Situational leadership is examined in relation to the followers. The theme of the leadership model is that a leader must be flexible. He must be able to adapt different styles to a situation based on the readiness level of the followers. For a successful leader is one who adapts his leadership style (task and relationship behavior) based on that level of readiness.

In addition, the situational ethics applied by Caesar in his actions will be examined. Throughout the primary source analyzed, an emphasis on the ethics of the situation can be demonstrated.

In analyzing the task behavior and relationship behavior established in the primary source of Caesar, the match of the readiness level of the followers to the appropriate leadership style found in the Model of Situational Leadership will be utilized. In this Model, Hersey and Blanchard match an (R1) low readiness to an (S1) telling leadership style, an (R2) low to moderate readiness of the followers to an (S2) selling leadership style, an (R3) moderate to high readiness to (S3) participating leadership style, and an (R4) high readiness level of the followers to an (S4) delegating leadership style.

After Caesar had defeated his first foe, the Helvetii in $58 \mathrm{BC}$, he was confronted by the Germanic horde under the leadership of Ariovistus. Many of his men and, in particular the officers, were very concerned if not terrified. Many discussions among the troops focused on where they were heading and why.

When I saw how things were, I summoned a meeting of officers reprimanding them severely for imagining that it was any of their business. to discuss or even think about where they were being led or for what reason. ${ }^{17}$ 
Caesar as a leader did not consider it necessary to inform his troops or provide them with a rationale. Caesar was not in Gaul for a higher moral purpose. Military success in Gaul would be a stepping stone to political power. Ethically, Caesar was acting from the perspective of the ethic of ultimate ends with that end being raw political power. To convince his troops to fight would lead him to that ultimate end.

At this time, Caesar realized that he was in trouble. He was in a hostile environment, east central Gaul, surrounded by potentially hostile Gauls and a large band of warlike Germans were approaching. His men knew well the circumstances that they were facing. They were however, the most highly trained and disciplined fighting machine in the ancient world. In Caesar's own words to his troops, "These Germans are the same people whom the Helvetii have often fought and very often defeated both in Germany and in their own country; yet the Helvetii could not stand up to our army."18

Based on his evidence it appears that Caesar knew that his men were, as defined by Hersey and Blanchard in their Model of Situational Leadership, at readiness level (R3). The above situation indicates that Caesar knew that his men were insecure. This insecurity was based on their lack of numbers, distance from Rome, and immediate location. According to the model, when the followers are at the (R3) readiness level the appropriate leadership style to apply is (S3) participating. This leadership style is low task and high relationship behavior. Caesar did not apply this style (See Figure 1) but rather applied the (S1) telling leadership style. The telling style is appropriately used when the followers are unable and unwilling to perform a specific task. However, his tactic 
worked. In his own words,

My speech had a remarkable effect. There was a complete change of heart and now everyone was eager to go into action at once. ${ }^{19}$

Clearly, Julius Caesar, in this example, did not appropriately match the leadership style with the readiness level of his followers as suggested in Hersey and Blanchard's Model of Situational Leadership and yet he was successful because his legionnaires went out and chased the German warriors all the way across the Rhine.

Julius Caesar's men, as mentioned earlier, were the best trained fighting force that the world had yet seen. His officers for the most part had fought with the army before and the centurions, the officers commanding the centuries - approximately one hundred men, were battle hardened veterans. Their readiness level was (R3). They were able. The ability was based on training. The Roman legions, a force of approximately 3,000 - 6,000 foot soldiers, fought in three lines. The first line was the youngest men, the second, the next youngest in age, and the third line, held in reserve, were the battle tested veterans. Roman tactics were to hurl javelins at the approaching enemy or at their foe while they charged. The javelins were made so that once impaled upon enemy shields, they were difficult, if not impossible, to withdraw. Many times the shields would then become useless and be tossed aside making the enemy vulnerable to the short stabbing sword of the legionnaire.

Gallic tactics were different. Michael Grant in his History of Rome notes:

In many parts of their huge unconquered tribal territories lying north of the Transalpine Province, the Gauls practiced advanced agriculture, animal breeding, and working of metals. But in spite of their fine cavalry, their capacity in battle was limited: once the initial charge of their horsemen and sword-bearing infantry had been held up, their attacks soon degenerated into anarchic disorder. ${ }^{20}$ 


\section{JULIUS CAESAR}

LEADERSHIP STYLES

\begin{tabular}{|c|c|}
\hline S3 & $\mathbf{S 2}$ \\
\hline $\begin{array}{l}\text {.C } \\
\text {.D }\end{array}$ & $\begin{array}{l}. \mathrm{A} \\
. \mathrm{B}\end{array}$ \\
\hline S4 & S1 \\
\hline
\end{tabular}

READINESS LEVEL OF FolLOWERS

\begin{tabular}{l|l|l|l}
$\mathbf{R 4}$ & $\mathbf{R 3}$ & $\mathbf{R 2}$ & $\mathbf{R 1}$ \\
\hline .C & .A & &. B \\
D & & &
\end{tabular}

Situation $\mathrm{A}=\mathrm{A} \quad$ Before the Heveltii (S1 - R3) Situation $\mathrm{B}=. \mathrm{B} \quad$ Legionaries Unable (S1 - R1) Situation $\mathrm{C}=. \mathrm{C} \quad$ Men acting on their own (S4 - R4) Situation $\mathrm{D}=. \mathrm{D} \quad$ Invasion of Britain (S4 - R4)

Figure 1 
The Gauls did not posses the discipline and order of their Roman adversaries. The Gauls fought as an undisciplined horde as opposed to the strict order of the Romans.

The Romans relied on infantry and were able to conquer much of the ancient world because until the 300's and 400's AD they never faced an army which had large numbers of cavalry. If they had, they might never have achieved the fame that their superbly disciplined legions won for them.

The Romans, encamped before Ariovistus and his Germans in $58 \mathrm{BC}$, were able but were insecure in their ability (R3). Julius Caesar contradicted the leadership style Hersey and Blanchard said should have appropriately been applied by applying an (S1) telling style. In fact according to their model, when an (S1), telling leadership style is applied in a specific situation; when the followers are at an (R3) readiness level the probability of success is low. The possibility, in terms of Hersey and Blanchard's Model which could explain this contradiction in the application of a leadership style to a readiness level of the leader's followers, which yet led to a successful result, hinges upon defining the followers level of ability. While, as explained earlier, the legion was the most disciplined and trained fighting unit in the ancient world, they could have been rendered unable by fear and anxiety The Romans, before Ariovistus were able but unwilling. Therefore, they actually demonstrated the (R1) low readiness level. Caesar, in this specific situation applied the (S1) telling leadership style. This style appropriately matched the readiness level of his followers (See Figure 1).

Caesar was a leader who constantly observed his troops to determine their level of readiness. While before the Germans he stated, "I decided to avoid battle for the time 
being, though everyday cavalry engagements took place in which I was able to test the enemy's fighting qualities and also to see how our own troops stood up to them."21 Caesar was testing the readiness level or morale of his troops. Sun-Tzu, in his text on war stated:

"High morale" in the Chinese text reads, "nu." In Modern Chinese this means only rage, anger, or ferocity. ${ }^{22}$

Caesar was measuring the ferocity, anger, and readiness of his men for battle. This situation is one example of the methods Caesar applied to determine the readiness level of his followers.

Caesar again refers to the readiness level of his troops in the Commentaries.

As the enemy were practically upon us, there was simply not time for doing most of these things, but in this very awkward situation we were helped by two factors. First, the training and experience of the troops themselves, who from their knowledge of previous battles were able to dispense with orders and judge on their own what should be done; and second, the order which I had issued to commanders of legions, instructing each of them to stay with his own unit while it was at work and not leave until fortifications were finished. They didn't need to wait for orders from me. $^{23}$

In this excerpt, Caesar does exhibit the (S4) delegating leadership style (See figure 1). He tells his commanders that they and their men are competent, able to act on their own based on their experience in previous battles. The followers readiness level in Caesar's own words was able and willing. They were, in this situation in the text, at an (R4) high readiness level. Here, Caesar successfully matched his leadership style with the readiness level of his followers.

Occasionally, Caesar had to take action that would impact the readiness level of 
his troops. In particular this would be done in the heat of battle when it was difficult to measure readiness level or decide which leadership style would be most appropriate in that situation. While in the midst of such a battle, Caesar determined that it was a critical moment against the Gallic tribe they were engaged in battle with and said,

Having no shield with me, I snatched one out of the hands of a soldier in the rear ranks and went forward. My arrival put heart into the men and gave them fresh confidence. Each of them, under the eyes of the Commander in Chief, wanted to do his best at whatever risk to himself. ${ }^{24}$

In this battle, his outnumbered army was at risk of defeat. By injecting himself into the melee, he raised their confidence and thereby increased the readiness level to (R4) high readiness. They were once again able and willing. Caesar was not utilizing (S1) telling, (S2) selling, or (S3) participating leadership styles. He was applying the (S4) delegating leadership style because he was not providing direction. He was not giving orders, he was simply providing an example to his men.

Caesar's legionnaires did not always exhibit an able and willing level (R4) of readiness. When Caesar invaded Britain for the first time, they exhibited the readiness level of (R1) low readiness. As the Roman ships pulled up onto the beaches of Britain Caesar noted, "They had no experience at all of this sort of warfare, and they failed to show the enthusiasm which would be exhibited of them in battles on land."25

At the moment that those ships hit the beaches Caesar's men froze. The men were confronted by a new situation that they had never confronted before, an amphibious assault. Caesar should have immediately applied, if he were following Hersey and Blanchard's Model of Situational Leadership, a telling (S1) leadership style and told his 
followers to jump to the beach and prepare to fight, for the Britons were charging down from the heights. Fortunately for Caesar, one of his own men provided a sense of direction.

Then as our men hesitated, chiefly because of the depth of the water, the man who carried the eagle of the 10th legion, after praying to the gods that what he was about to do would bring luck to the legion, shouted out in a loud voice, "Come on men! Jump, unless you want to lose your eagle to the enemy. In any case I will do my duty to my country and my general.",26

The readiness level of the men immediately rose to (R4) able and willing. Caesar no longer had to operate under the telling style. In that his eagle bearer was acting without direct orders, it could be argued that Caesar was in fact operating in the (S4) delegating leadership style, once his men jumped onto the beach, following the example of the brave soldier from the 10th legion. He did not have to provide direction nor did he in this situation (See Figure 1).

Again, during the course of the Commentaries, Caesar attempts to measure the readiness level of his legions. In his war with Vercingetorix, he laid siege to the fortified town of Bourges. It was an action which led to severe circumstances which his troops had to bear.

I used to go and speak to the men of each legion while they were working.

I would tell them that, if they found their privations unbearable, I was quite ready to raise the siege; but one and all begged me not to do so. ${ }^{27}$

Here Caesar is getting some participation. This seems to indicate that he is flexible, able to adapt to situations.

His men, during the siege, were still at the level of (R4) high readiness. It was important for him to know this for his situation was becoming desperate. 
During the Civil War, when Caesar had Pompey's troops pinned at Brindisi, he addressed his troops.

The troops broke into cheering and told me to give them whatever order I liked. They would gladly do whatever they were asked. ${ }^{28}$

As he spoke to his troops prior to this battle of the Roman Civil War, the above evidence indicates that once again he checked the readiness level of his followers and found them to be at (R4) high readiness — willing and able.

According to Caesar's own account of his military campaigns he primarily, appropriately matched leadership styles to the readiness level of his followers during each specific situation. In addition, the ethics of those situations would cause Caesar to adopt his directions accordingly. However, it did seem that he generally acted with the best interest of his men as a continual goal. His actions are evidence that while the preservation of his men might not have been his ultimate end, it surely was important.

Caesar constantly checked the readiness level of his followers and usually adjusted his actions accordingly. The probability of his successes in the field were generally high because as evidenced by his own words in the text, he matched his leadership to the readiness level of his followers based on the task of the specific situation.

As a leader, Caesar had to make decisions to successfully influence the behavior of the followers. A good leader will adjust those actions based on different situations. While his governorship/generalship beginning in $58 \mathrm{BC}$ was a stepping stone to political power, Julius Caesar learned many techniques that would benefit him later, if only for a 
few brief years, as the sole dictator of Rome.

Hersey and Blanchard's Model of Situational Leadership is a connection between 1) the amount of guidance and direction (task behavior) a leader gives; 2) the amount of socio-emotional support (relationship behavior) a leader provides; and 3) the readiness level that followers exhibit in performing a specific task. The War Commentaries of Caesar provide evidence of a leader in the history of western civilization who did embrace characteristics of situational leadership. He regularly checked the readiness level of his followers. Caesar applied different leadership styles in different situations. However, he did not apply different leadership styles to match the readiness level of his troops. He did not always match (S1) telling leadership with an (R1) low readiness of his men, an (S2) selling leadership style with an (R2) low to moderate readiness level of his troops, an (S3) participating leadership style with an (R3) moderate to high readiness of his followers, or an (S4) delegating leadership style with an (R4) high readiness level of his legions. All of the above matches would suggest, according to Hersey and Blanchard, a high probability of success. As mentioned in the Commentaries there were times that he imposed mismatches but as evidenced in his text he did also at times match his leadership style with the readiness level of his followers. From evidence gathered, it is clear that Caesar usually. correctly matched leadership styles to the readiness level of his troops. This matching led to the successes which are predicted in Hersey and Blanchard's Model of Situational Leadership. 


\section{JULIUS CAESAR AND THE ETHICS OF THE SITUATION}

In examining the ethics of the situation, the researcher may turn to Max Weber's dualistic model of the two ethics - the ethic of responsibility and the ethic of ultimate ends. James MacGregor Burns states the following:

In a famous distinction Max Weber contrasted the "ethic of responsibility" with the "ethic of ultimate ends". The latter measured a persons behavior by the extent of their adherence to good ends or high purposes; the former measured action by a persons' capacity to take a calculating, prudential, rationalistic approach making choices in terms of not one supreme or value hierarchy alone but many values, attitudes, and interests, seeing the implication of choice for the means of attaining it - the price paid to achieve it, the relation of one goal to another, the direct and indirect effects of different persons and interests, all in a context of specificity and immediacy, and with an eye to actual consequences rather than lofty intent. $^{29}$

According to Weber, the ethic of ultimate ends was a value system that was broad and exalted. While the ethic of responsibility was the day to day application of leadership that was much narrower in nature. The leader, embracing the ethic of responsibility has a clear vision of the consequences of his actions or inactions.

Weber's ethic of ultimate ends can be thought of as the overall framework by which a leader makes decisions to influence followers. The ethic of responsibility then becomes the day to day activities of leadership demonstrated to achieve that ultimate end. In the primary source examined in this research there are examples of Caesar's ultimate end - supreme power!

While Caesar was preparing to meet the Germans of Ariovistus he commented, "It is the way of Romans to want our friends and allies, rather than lose what belongs to them to be constantly growing in influence, importance, and prestige."30 This is a contradiction 
in terms of the ethics of the situation. Caesar's overall ethical perspective would be considered the ethic of ultimate ends, he ultimately wanted supreme power and yet in this situation, at least in his own words, it is understood that there may be a higher good. Rome, at least according to Caesar's own words did not want to conquer and wrest away all of the conquered belongings but rather to let their friends and allies grow in power as Rome grew.

Did Caesar adhere to a truly moralistic and loftier end or did he use the phraseology when necessary, which would actually be the ethic of responsibility - a rationalistic, practical outlook?

Caesar treated his allies, the Aeduci of Gaul, with respect and saw to it that they grew in power and influence. He allowed the Helvetii to return to their land once they had been defeated but this was to create a buffer zone between Gaul and the warlike Germans. Caesar is seen to apply the ethics of the situation differently in various situations based on his goals.

Once again in the Commentaries Caesar points out his underlying "loftier goals" perspective towards the ethic of different situations. While preparing to lay siege to a fortified Gallic town, he relayed to their leader, "If they surrendered before a batteringram had touched their walls, I would spare their lives, but that I was showing them mercy rather because it was my nature to be merciful than because they deserved such treatment." ${ }^{\prime 31}$ In this situation Caesar exhibited the loftier goal, or in Weber's terminology "right goals", in regards to the ethics of that situation. 
Caesar was not always so magnanimous in victory. After capturing a Gallic town that put up a stiff resistance he said,

Thus after great losses, the survivors had nothing on which to fall back on and no means of defending their strongholds. They therefore surrendered to me unconditionally. I decided that they should be treated severely, so that in the future the natives should be taught to respect more carefully the laws respecting the rights of envoys. ${ }^{32}$

The town was destroyed and all of the inhabitants were slaughtered or sent into slavery. All of this, according to Caesar was meant to send a message that Roman envoys were to be respected by everyone at all times. In this situation Caesar was acting from the perspective of the ethic of the ultimate ends. He had a goal and he went about in a practical manner to achieve that end - wholesale destruction of a town.

Soon after Caesar found himself in a different situation and exhibited a loftier, somewhat more noble ethic.

There was the question of the Ubii - the only tribe across the Rhine which had sent representatives to me, entered into a friendly alliance, and given hostages. The Ubii were now asking me most urgently to come to their help against the Suebi, who were exercising severe pressure on them. ${ }^{33}$

In this situation the Ubii were on friendly terms with Rome. Caesar, in this situation, acted accordingly. It appears that he treated them as friends. This was practical because the evidence indicates Caesar calculated that since they were friendly, he would reciprocate. Based on Caesar's actions, it appears that his goal towards the Ubii was to maintain friendly relations, which was different from his goals for other Germanic tribes which were based on different, less friendly relationships. This was a practical model and in this situation would fall under the definition of the ethic of the responsibility. 
During the siege at Bourges, Caesar also exhibited characteristics that could be identified as part of the ethic of ultimate ends.

Our troops were furious at the enemy's daring to stand waiting for them at such close range and clamored for a signal to charge, but I explained to them that victory here would be a costly business and could be won only by the loss of many, gallant lives. I told them that, after I had seen them so ready to face any danger in order to win me glory, I should myself be guilty of the worst sort of injustice if I failed to put their own lives first and my own interests afterward. ${ }^{34}$

His behavior and comments in this situation were aimed towards a "good end", the sparing of any unnecessary loss of their lives for the purpose of gaining glory for a general.

While Caesar was out plotting for Rome, the Senate and his sometime political rival Pompey were plotting against him. Eventually, as the Gallic Wars were winding down, tensions were building which would lead to the Roman Civil War.

Caesar was in fact trying all along to bring about a solution to the issues between himself and Pompey.

I realized that these constant efforts of mine to reach understanding were handicapping me both in action and in planning for the future.

Nevertheless I thought that on all accounts I ought to go on trying for peace. $^{35}$

Once again, Caesar exhibited the ethic of responsibility in this specific situation by trying to maintain a lofty goal — peace between he and Pompey. Caesar according to his writings did not want to bring about a civil war. When his men met Pompey's force, Caesar once again exhibited the ethic of responsibility.

However, now I had cut the enemy off from his supplies. I hoped to fight or to expose my own men to danger. Why should I lose any of my own 
men even in a victory? After all, a good general should win victories by intelligence just as much as by brute force. Then too I felt compassion for my own fellow countrymen and who would certainly be killed if there were a battle. ${ }^{36}$

In this situation, Caesar's ultimate end was the preservation of his men. Yes, it could have been for the practical reason that he needed them to fight again which would be characteristic of acting from the perspective of the ethic of ultimate end but based on his constant concern for his men's welfare this is doubtful. It would seem that he truly believed that good generals won by intelligence and not through simply outlasting the killing of their own men.

The essence of Situational Leadership is the concept that to be successful the leader must adapt leadership style to the readiness level of followers to perform a specific task. The leader does not select the style in a vacuum. The ethics of the situation have an effect on the selection of those decisions. Based on Weber's distinction, contrasting the "ethic of responsibility" with the "ethic of ultimate ends", a leader's behavior is measured by their actions. If a leader is acting in a practical, opportunistic, self-serving, manner he is demonstrating the ethic of responsibility in that specific situation. A leader whose behavior can be measured by their adherence to lofty intent or higher purpose is reflecting the ethic of ultimate ends.

As Julius Caesar measured his legionaries readiness level and chose a leadership style to match, the consequences of those actions were examined. As he moved from one specific situation to the next, his leadership style and situational ethic was altered.

Evidence from the Commentaries note that in one situation Caesar would be 
magnanimous to his foe and in other situations would be utterly ruthless. He matched his decisions to the Model of Situational Leadership but also to the ethic required for that situation. His ultimate goal was power and he judged the situation and the ethic to be applied by this goal. What was necessary to attain power was his constant thought. His military career provides the evidence of his varying ethical decisions.

Julius Caesar was a leader who achieved tremendous military and political success before his assassination. His success was predictable because of the matching of leadership style to the readiness level of his followers in a specific situation. He did not always operate from the ethic of the ultimate end. He treated some enemies fairly, he was ruthless towards others, and he claimed that he tried to spare the lives of his men all for one reason - supreme power. 


\section{CHAPTER II NOTES}

${ }^{1}$ J. F. C. Fuller, Julius Caesar (New Jersey: Rutgers University Press, 1965), 20.

${ }^{2}$ Ibid., 20.

${ }^{3}$ Arthur E. Boak and William G. Sinnigen, A History of Rome $753 \mathrm{BC}$ to $565 \mathrm{AD}$

(New York: MacMillan Co., 1968), 242 - 243.

${ }^{4}$ Lewis Naphtali and Meyer Reinhold, Roman Civilization (New York: Columbia University Press, 1967), 235.

${ }^{5}$ Arthur D. Kahn, The Education of Julius Caesar (New York: Schocken Books, 1986), 13.

${ }^{6}$ Ibid., 6.

${ }^{7}$ J. P. V. D. Balsdon, Julius Caesar: A Political Biography (New York: Atheneun, 1967), 2.

${ }^{8}$ R.H. Barrows, The Romans (Chicago: Penguin Books, 1949), 46.

${ }^{9}$ Ibid., 53-54.

${ }^{10}$ Ibid., 54.

${ }^{11}$ Robert Payne, ed. William Harlan Hale, The Horizon Book of Ancient Rome (New York: American Heritage, 1966), 163.

${ }^{12}$ Plutarch, Lives of Thermistocles, Pericles, Aristid Alcibades and Cariolanus, Demosthenes and Cicero, Caesar and Anthony, trans. Arthur Hugh Clough (New York: P. F. Collier and son, 1909), 298. 
${ }^{13}$ Fuller, 166.

${ }^{14}$ Ibid., 54.

${ }^{15}$ Ibid., 91 .

${ }^{16}$ Boak and Sinnigen, 243.

${ }^{17}$ Julius Caesar, War Commentaries of Julius Caesar (New York: Amereon, Ltd., 1976), 34 .

${ }^{18}$ Ibid., 32.

${ }^{19}$ Ibid., 32.

${ }^{20}$ Michael Grant, History of Rome (New York: Charles Scribner's sons, 1979), 215.

${ }^{21}$ Caesar, War Commentaries, 34.

${ }^{22}$ Sun-Tzu, The Art of War, reinterpreted by J. H. Huang (New York: Quill William Morrow, 1993), 138.

${ }^{23}$ Caesar, War Commentaries, 50.

${ }^{24}$ Ibid., 52.

${ }^{25}$ Ibid., 82.

${ }^{26}$ Ibid., 82.

${ }^{27}$ Ibid., 145.

${ }^{28}$ Ibid., 280.

${ }^{29}$ James MacGregor Burns, Leadership (New York: Horton Torchbearer, 1978), 
${ }^{30}$ Caesar, War Commentaries, 34.

${ }^{31}$ Ibid., 54-55.

${ }^{32}$ Ibid., 64.

${ }^{33}$ Ibid., 77.

${ }^{34}$ Ibid., 146.

${ }^{35}$ Ibid., 226.

${ }^{36}$ Ibid., 246. 


\section{CHAPTER III}

\section{NICCOLO MACHIAVELLI}

\section{HISTORICAL BACKGROUND}

To understand the relationship between the leadership style and the situational ethics exhibited by Niccolo Machiavelli and the characteristics of Hersey and Blanchard's Model of Situational Leadership, the researcher must examine the historical context of the era in which Machiavelli lived. The historical context of the late fifteenth and early sixteenth century, including the socio-economic, political, and military perspectives of the era, will be analyzed in order to comprehend possible motives for Machiavelli's leadership style and ethical choices.

In describing this transition period, Ernest and Trevor Dupuy note:

Historians generally agree that the Middle Ages ended with the close of this century. This was no abrupt change, however, and it was symbolized by the following, primarily military events: the fall of Constantinople, the end of the Hundred Years' War, the end of the War of the Roses, and Charles VIII's invasion of Italy. ${ }^{1}$

Over time this period, after the middle ages, came to be known as the Renaissance. The term Renaissance had many meanings. Robert Ergang's text on the Renaissance, defined it in the following manner:

In describing the break-away from the old traditions the Renaissance writers employed a number of metaphors. The one used most frequently was that of awakening from a long sleep or emerging from a state of topor. 
The metaphor of rebirth came into use very gradually but in time displaced the others. ${ }^{2}$

The Renaissance, which began in the fifteenth century, came to be known as an awakening or a rebirth. The philosophy, art, literature, or histories, etc. of the ancients were revived in all facets of political, socio-economic, and military life. Authors, artists, and politicians came to rely on the ancient Greeks and Romans for inspiration. John Hale stated, "At nearly every point, antiquity offered a comparison to be made with the long inheritance of chivalrous, feudal and christian values; indeed, both Reformers and counter-reformers dipped their pens into the vast pool of classical ink." ${ }^{\prime 3}$ The ancients were held up as examples by many throughout this era.

The above statement by Hale touches upon the ecclesiastics' use of ancient models during the Renaissance but the Renaissance did not focus on religion. Ergang states, "Thus the Renaissance is the transition from a civilization which had the hereafter as the central idea to one which is roofed in mundane affairs." ${ }^{.4}$ Mundane affairs being the actions and activities of an ordinary, daily life. Ergang further states, "Secular pertains to the present life and the visible world as distinguished from "other worldly" which refers to or implies concern for a future existence after death." Renaissance life dealt with the ordinary, visible life of the present.

From this concern with the secular world, rose the doctrine of humanism. John Hale describes it as follows, "It was from the fifteenth century Italian "umanista," the man who used the texts to teach the literae humaniores, the branches of study most concerned with the secular human condition (grammar and eloquence, history poetry, and 
moral philosophy) that the word humanism was invented in the nineteenth century to describe the conditioning of ideas that drew on a knowledge of classical antiquity." Humanism focused on the human condition. The doctrine was concerned with human beings and their activities, not life in the hereafter. Hale notes, "Though humanism presented the merits of a pagan civilization to a Christian one, it became naturalized with little strain."

The Renaissance was a rebirth. It was a rebirth of the ancient perspective that viewed the world through the ordinary affairs of humans and focused on the present, not the hereafter. Ancient Greece and Rome became the models which guided artists, architects, musicians, writers, politicians, and generals of the age.

Florence, the city of Machiavelli, was part of the overall historical period known as the Renaissance and more specifically as the Italian Renaissance. The Italian Renaissance began in the fifteenth century and ended with the destruction of Rome. Ergang states:

But the flowering of the Renaissance in Rome was of brief duration. In 1527, five years after the death of Leo X, the army of the Emperor Charles $\mathrm{V}$ of the Holy Roman Empire sacked the Eternal City, scattering the artists and scholars in all directions. By this time the Renaissance had lost much of its vitality in Italy. ${ }^{8}$

In fact Rome wasn't destroyed during the Renaissance. It was sacked much earlier in the fifth century. It was sacked again in 1527 but was not destroyed.

While the Renaissance was flourishing in Italy, Florence produced many famous men. Robert Ergang states, "No city of the Christian era has given to culture and to the world such a galaxy of men of high achievement." ${ }^{\text {"9 }}$ Niccolo Machiavelli was part 
of this galaxy of men of high achievement who, within the framework of humanism and secularism, laid out strategies for leaders of his era to operate within the world of politics and war.

The political framework of Italy differed from France and England during the Renaissance. According to Ergang:

The Italy of the Renaissance was not a nation like France or England. It was a country without political unity. ${ }^{10}$

Italy had no central government. It was not the nation-state that typified the development of France and England. In fact Italy was made up of many separately governed city-states. Ergang describes the city-states in the following manner:

The city-states differed from each other in many ways. While some were ruled by despots, others had governments that were democratic in spirit. Each city-state had its own laws, its own currency, its own military force, and its own economic interests. ${ }^{11}$

Unification for Italy would not come until the nineteenth century and until then, Italy resembled ancient Greece more than the more modern nation-states of Western Europe. In the meantime, including throughout the Italian Renaissance, the city-states, such as Florence continued to exist as separate political entities.

The rules were changing for the leaders operating in the political world of the Renaissance. Hale described a strategy for the statesman of this era:

But already the idea of knowledge based on practical experience was gaining ground. Machiavelli, though a lover of book-knowledge, stressed the statesman's need to study the actual condition of affairs. ${ }^{12}$

Writers, including Machiavelli began to produce guides for leaders of this time which were based on practical experience. Given the complexity of the city-state political 
structure during the Italian Renaissance, the writers had a ready and willing group of clients.

The Renaissance was an age of transition. It was a transformation from the ecclesiastical to the secular. According to Robert Ergang, "The cradles of the new secular culture were the commercial towns, some of them were old towns which had been reactivated by the expanding commerce and others were new towns founded as centers of commerce." 13

The city-state structure of Italy in this period had negative ramifications politically but the reverse was true economically. During this period an economic depression occurred and as Ergang noted:

The Italian City-States with their highly developed economic systems were able to withstand the blow better. Despite the economic slow-down and the recession which followed, the economics of the major Italian States still continued to function at a high rate. ${ }^{14}$

The city-states were not unified politically, but exhibited an economic vitality that was not seen in other countries of the period.

This economic vitality was based on trade. Along with the economic vitality, the population all over Europe was growing. John Hale stated, "Meanwhile as Europe's population grew, and a more sizable minority of the well to do emerged, the demand for more than the necessities of life extended and with it a stimulus to the traffic in goods and silks." ${ }^{15}$ This minority of wealthy families applied a certain type of pressure. Hale further notes, "Some families, even rich and noble ones, continued to live austerely; overall, however, the social pressure to use surplus money to furnish and embellish was an 
infectious part of the age of more." change society by their wants and needs. Part of this minority was a new middle class. The middle class accumulated their wealth in several ways. Ergang said, "The wealth accumulated by members of the middle class from trade, industry, and banking opened the way to the enjoyment of the good things of life and generated a secular spirit which was the motive power in the rise of a new secular culture."17

One of the above mentioned newly powerful families were from Florence. Ergang describes the family:

One Florentine family stands out above all others as patrons of learning and the arts. It is the Medici Family which became wealthy through commerce and banking. Although conditions were not particularly favorable for international banking, the Medici achieved success by adopting better principles of organization and by employing superior banking techniques. ${ }^{18}$

As patrons the Medici did much to support the secular culture of the Italian Renaissance. Through their patronage artists, architects, and writers, including Machiavelli, were able to ply their craft and share their works with the world.

Italy, during the Renaissance, was a nation comprised of many city-states. The city-states had separate governments but many were economically well-off. This scenario was problematic militarily for the region. Ernest and Trevor Dupuy relate:

Italy - weak, fragmented and wealthy - was the principal battleground of the great wars between France, Spain, and the Hapsburgs during the first half of this century. The almost continuous minor wars between the petty Italian States were merely incidents in these larger struggles. ${ }^{19}$

Because of their fragmented but rich state, Italy became the site of wars both big and small. The constant warfare drew comparisons to the ancient world. The Dupuy's 
state, "Many small states of Italy were then at war with each other and with neighboring countries and in this respect Italy has been compared with Greece in the third and fourth centuries $\mathrm{BC}^{\prime 20}$ The armies that fought these wars were changing. The Dupuy's state, "The armies of fifteenth century Italy placed much greater importance on heavily armored men-at-arms, almost entirely in mercenary units.",21 They further note, "These mercenaries were called condottieri after the Italian word for contract, condotta."22 The condottieri system did not help to create a strong or unified nation for it was not an effective system. The condottieri system was described in the Dupuy's text in the following manner:

The traditional - and essentially accurate view of warfare under condottieri, exemplified by the acerbic comments of Niccolo Machiavelli is that it was desultory, nearly bloodless, and generally pointless. There were, however, several reasons Mercenary commanders were generally reluctant to incur heavy casualties, since their soldiers represented their operating capital and their only method of generating income. ${ }^{23}$

The condottieri system with all of its problems did not last forever. The end of the condottieri system and the demise of the Italian Renaissance occurred simultaneously. As stated by the Dupuys, "The condottieri's house of cards collapsed when Charles VIII of France led a hard fighting professional army into Italy toward the close of the century., 24 The fragmented political landscape along with the wealth of the city-states was too tempting for the King of France. While not immediate, after this invasion the power of the city-states ebbed away.

The historical context of the Italian Renaissance found a region that was rich economically but terribly fragmented politically. The newly created wealth allowed for 
the patronage system amongst the middle and upper class which led to the spread of humanism and secularism. Culturally Italy was rich but politically weak. Machiavelli was a patriot. He yearned for a Italy which would have the political, socio-economic, and military strength to drive out all of the foreign invaders. From this perspective he wrote The Prince, The Discourses, and The Art of War.

\section{WRITINGS OF NICCOLO MACHIAVELLI}

The primary sources used to analyze whether or not Niccolo Machiavelli embraced characteristics of both Hersey and Blanchard's Model of Situational Leadership and Situational Ethics are The Art of War, The Prince, and The Discourses. Each source, written by Machiavelli, was meant to be a blueprint for leadership during the Italian Renaissance. Machiavelli's purpose in writing was to demonstrate methods for transforming a weak Italy into a force powerful enough to rival France and England.

The Art of War is a description of a discussion held amongst a circle of friends in Renaissance Florence. Fabrizio Colonna, one of the friends and a soldier, delivers a monologue throughout a majority of the text. This monologue analyzes the state of the Italian art of war. Machiavelli, through the voice of Fabrizio, champions the resuscitation of the art of war by recommending the creation of a citizen's militia to replace the mercenary system of warfare. The citizen's militia proposed by Machiavelli, through Fabrizio's monologue, is based on the ancient Roman military structure. The text was in fact the first modern attempt to revive classical military thought and apply those principles to contemporary problems. 
The Art of War is the summarization of Machiavelli's political doctrine. In it he defines a functional unity between politics and war. According to Neal Wood in his introduction to The Art of War:

Machiavelli evidently believes that the basic relationships between the arts of war and politics are as follows:

1. Military power in the foundation of civil society.

2. A well-ordered military establishment is an essential unifying element in civil society.

3. A policy of military aggrandizement contributes to the stability and longevity of civil society.

4. The military art and the political art possess a common style.

5. A military establishment tends to reflect the qualities of the civil society of which it is a part. ${ }^{25}$

To Machiavelli, war is simply a means to a political end. War becomes an arm of the political machine.

The Art of War opens with a gathering of friends to discuss politics, philosophy, and literature. Book I of The Art of War outlines the deplorable condition into which the military had fallen. In Book II, Fabrizio examines the training, organization, and arming of his proposed citizen's militia. In the Third Book of The Art of War a description of classical battle formation and methods is outlined. Included is the examination of a model battle following the lessons from the previous description of Ancient Greek and Roman Methods. The topics of Book IV are tactics and planning to be used during and after a battle. The order of March is covered in Book V, encampment and the welfare of troops is the topic of Book VI, and the defense and attack of towns is outlined in Book VII. Machiavelli, through the subjects covered in The Art of War, attempted to revive classical military thought. His objective, as mentioned, was to strengthen a weak and 
prostrate Italy.

Machiavelli's The Prince is described by Leo Strauss as follows, "The Prince is a scientific book because it conveys a general teaching that is based on reasoning from experience and that sets forth that reasoning. ${ }^{26}$ The text is meant to teach. Its' message is meant for the rulers of the Italian peninsula in general and Lorenzo de Medici in particular.

The Prince is structured in four parts 1) the different kinds of principalities, 2) the prince and his enemies, 3) the prince and his subjects or friends, 4) prudence and chance. The book opens as a scientific treatise, detached from its subject matter but ends with a call to arms, very much connected to its goal the strengthening of the Italian princes and states to drive out the invaders.

The Prince is a blueprint for the liberation of Italy. Machiavelli is a patriot and the teachings of The Prince, no matter how repulsive, are meant to achieve this goal. The end justifies the means holds true throughout the text. It is also one of the early books on educating the leader. Machiavelli was not the leader but was the educator of the leader. This makes him a different subject than either Caesar or Napoleon.

To liberate Italy was to conquer Italy and the conqueror, according to Machiavelli, must spare no means to attain this end. A policy of iron, poison, and treachery must be followed. In essence a revolution regarding thinking about right and wrong must begin and Machiavelli hoped to spark this revolution with the text. Many means are suggested to reach the end. 
The fundamental point of The Prince was according to Leo Strauss, "Concerning the prophets in general, Machiavelli remarks that all armed prophets have conquered and the unarmed prophets have failed. ${ }^{27}$ This coincides directly with the ultimate message of The Prince which is that the end justifies the means in creating a strong Italy.

In essence The Prince and to some degree The Discourses largely examines the problem of obedience in relation to whether or not the leader should seek to command on the basis of love or fear. The leader, according to Machiavelli, should be concerned with the end. In achieving the end the leader should be concentrating on being feared rather than loved by his followers. In using fear, however, Machiavelli's method is measured. Just enough fear to get the desired result.

The Discourses has a purpose which is to prove that the ancient modes and orders can be imitated by modern man. In particular, Machiavelli is referring to the Romans and he does this by analyzing the first ten Books of Living in his commentary on the Roman Republic. The Discourses differs from The Prince in that, in the latter Machiavelli is trying to get the reader to lose himself in the spirit of antiquity whereas in the former, Machiavelli notes the differences between modern and ancient man.

Machiavelli divided The Discourses into three books. The topics of each are as follows, 1)Book I - the internal affairs of Rome that were transacted on the basis of public counsel, 2)Book II - the foreign affairs of Rome that were transacted on the basis of public counsel, and 3)Book III - both private and public affairs of Romans that were transacted on the basis of private counsel. In the words of Strauss, "The characteristic theme of The Discourses is the people as the maintainer of established modes and orders, 
or as the repository of morality and religion." ${ }^{, 28}$ Machiavelli was a revolutionary.

Throughout this text, Machiavelli correlates new modes and orders with the ancient modes and orders. He jolts tradition with this radical thought which has as its foundation the philosophy that the principle of authority equates the good with antiquity.

The fundamental message of The Discourses is that in order to establish a republic, we must return to the beginning, a beginning where there was terror and men were good because they were easily frightened.

According to Strauss, "Machiavelli is the first philosopher who believes that the coincidence of philosophy and political power can be brought about by propaganda which wins over ever larger multitudes to the new modes and orders and thus transforms the thought of one or a few into the opinion of the public and therewith into public power." 29 Machiavelli's ultimate goal, throughout much of his writing was the creation of a strong Italy to drive out foreign invaders. The Discourses is one more piece of propaganda to be utilized to achieve this end. Using the revolutionary method of modeling his text on the ancients, the message of what Machiavelli feels is necessary to create a strong republic and therefore a strong Italy, is delivered throughout The Discourses. The text is patriotic propaganda at its best.

\section{NICCOLO MACHIAVELLI AS A SITUATIONAL LEADER}

To determine the extent to which Niccolo Machiavelli appeared to embrace or reject the leadership style characteristics found in Hersey and Blanchard's Model of Situational Leadership, the researcher examined the primary sources of Machiavelli. Analyzed will be the match between the leadership style and the follower readiness level 
in performing specific tasks.

In addition, the situational ethics applied by Machiavelli in his practical guide to leaders of the Italian Renaissance will be examined. In fact throughout the primary sources studied in this analysis, more emphasis is placed on the ethics of the situation than leadership style characteristics necessary for specific situations.

Machiavelli's The Art of War, has elements of a match between the (R1) and (S1) readiness level and leadership style. In the monologue, Fabrizio states:

As to the matter of compulsion, I reply that men selected by their princes' command should be neither all volunteers nor forcibly compelled into the service, for if they were all volunteers, the mischiefs which I just now mentioned would ensue, it could not properly be called a delectus and few would be willing to serve. Compulsion, on the other hand, would be accompanied by no fewer inconvenience; therefore, a middle course ought to be taken whereby - without either using men with outright violence or depending entirely upon their own voluntary offers - they may be motivated by the obedience they think due to their governors to expose themselves to a little immediate hardship, rather than incur their displeasure; and by these means (since their own will seems to cooperate with a gentle sort of compulsion) you will easily prevent those evils that might otherwise result from a spirit of licentiousness or discontent. ${ }^{30}$

In the above quote, Machiavelli declares that men should be brought to the service of the prince not as volunteers or forcible compelled but rather out of obedience to the leader - not wanting to incur his wrath. This statement describes a group of followers who are unable and/or unwilling (R1) readiness level. Machiavelli's leader does not respond by attempting to establish a high level of relationship but rather exemplifies the (S1) telling leadership style which according to Hersey and Blanchard focuses on high task relationship - namely war (See Figure 2). 


\section{NICCOLO MACHIAVELLI}

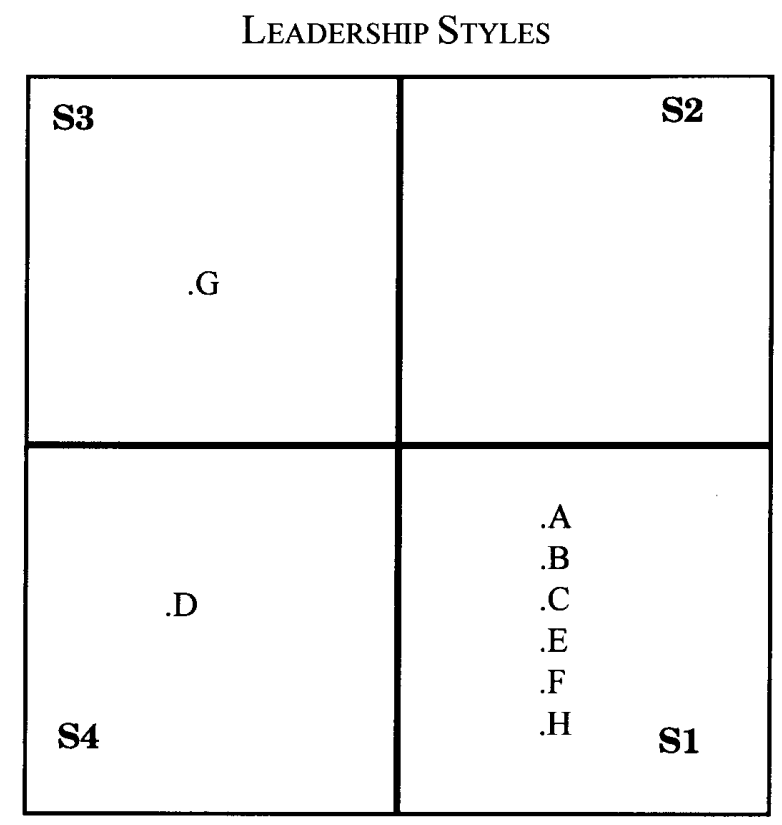

READINESS LEVEL OF FolLOWERS

\begin{tabular}{l|l|l|l}
$\mathbf{R 4}$ & $\mathbf{R 3}$ & $\mathbf{R 2}$ & $\mathbf{R 1}$ \\
\hline.$D$ &.$G$ & &.$A$ \\
& & &.$B$ \\
& & &.$C$ \\
& & &. $\mathrm{E}$ \\
& & & .F \\
& &
\end{tabular}

Situation $A=. A \quad$ Men brought serve out of obedience to prince

$(\mathrm{S} 1-\mathrm{R} 1)$

Situation $\mathrm{B}=. \mathrm{B}$

Men need to be inflamed to fight

$(\mathrm{S} 1-\mathrm{R} 1)$

Situation $\mathrm{C}=. \mathrm{C} \quad$ Times of stress

Situation $\mathrm{D}=\mathrm{D} \quad$ To prevent militia from overturning republic

Situation $E=. E \quad$ Whether it is better to be feared or loved

Situation $F=. F$ Feared rather than loved

Situation $\mathrm{G}=. \mathrm{G} \quad$ Fox or the Lion

Situation $\mathrm{H}=. \mathrm{H} \quad$ Fox or the Lion 
In times of war, men are not constantly in a state of preparedness for battle.

Machiavelli addresses this as follows, "As for the means of animating your men and inflaming them with a desire to fight, it would be good first to engage them against the enemy; to tell them they are despised; to insinuate that you have corrupted some enemy officers and hold a private correspondence with them; to camp in a location where you may daily see what they are doing and now and then skirmish with them; for things that are often seen eventually become familiar and are but little regarded. ${ }^{, 31}$ When men need to be inflamed to fight $(\mathrm{R} 1)$ readiness level, it is up to the prince to tell them, (S1) leadership style, what is necessary to get mentally prepared for battle (See Figure 2). Examples of the (R1) and (S1) Hersey and Blanchard match are also found in $\underline{\text { The }}$ Discourses. Machiavelli declares, "To avoid the necessity of having to spend his life suspecting people and displaying ingratitude, a prince should go in person on any expedition." 32 While this statement sheds no light on the readiness level of the followers in this specific instance, it does demonstrate the (S1) telling style of leadership. However, we do find that Machiavelli was definitely in favor of the (S1) telling style of leadership in times of stress. He remarks, "When danger was imminent, the Romans chose to appoint a dictator i.e., to give power to some one man to make decisions without consulting others and to carry them out without anyone having the right to appeal." 33 Machiavelli's message was clear that in moments of strain one man should be in sole control and that while in control the (S1) telling leadership would be applied.

Machiavelli looked to Rome, the dictatorship was found to be beneficial. Machiavelli notes, "Experience has shown that the dictatorship was always useful." ${ }^{34}$ In 
addition Machiavelli comments regarding the situation of the dictatorship:

Of Rome's various institutions this is one that deserves to be considered and ranked among those to which the greatness of Rome's vast empire was due. For without such an institution cities will with difficulty find a way out of abnormal situations. For the institutions normally used by republics are slow in functioning. ${ }^{35}$

In a dictatorship the (S1) telling form of the Model of Situational Leadership is exemplified. The leader, in a dictatorship, is ruling with a group of followers who are unable or unwilling and he applies a high task relationship to the situation. In, as Machiavelli notes, an abnormal situation, the (S1) telling relationship found in a dictatorship is more useful than the democratic institutions of republics where a more (S3) participating or (S4) delegating form of leadership style would be applied. In times of stress Machiavelli's advice is to apply (S1) telling leadership (See Figure 2).

In analyzing Machiavelli to determine whether or not he supports all of the elements of Hersey and Blanchard's Model of Situational Leadership contradictions are found. Machiavelli states, "Where gentry are numerous, no one who proposes to set up republics can succeed unless he gets rid of the lot." ${ }^{, 36}$ If Machiavelli were following Hersey and Blanchard's Model of Situational Leadership, in this specific situation the leader would apply a high relationship (S3) participating leadership style in order to secure success. He would not get rid of the lot!

Another contradiction to the model appears when analyzing the primary sources to determine if the (R4) high readiness and (S4) delegating leadership style can be found. In The Art of War Machiavelli, through the monologue of Fabrizio announces, "No man has ever founded a monarchy or a republic, without being well assured that if his subjects 
were armed, they would always be ready and willing to defend the monarchy or republic." ${ }^{\prime 37}$ The key words ready and willing in this quote are applied to the leader's followers. It would be, in the terminology of the model an (R4) high readiness level. However, no mention is made of matching an (S4) delegating leadership style to this follower readiness level. A monarchy or for that matter a situation governed by the institutions of a republic may not demonstrate low relationship and low task behavior of the leader. Again, it can not be seen that Machiavelli strictly adheres to Hersey and Blanchard's Model of Situational Leadership in its entirety.

In defining an able and willing group of followers as soldiers, Machiavelli notes "For this reason, I should prefer to choose husbandmen and men who have been accustomed to work in the fields as men more useful in an army than any other kind of person; next to these, I would take smiths, carpenters, farmers, and stonecutters, of whom it is necessary to have many, because they are often needed and it is a good thing to have soldiers who can turn their hands to more services than one."38 Machiavelli states what is necessary to gather an (R4) able and willing group of soldiers but there is no mention of corresponding (S4) delegating leadership characteristics.

However, in The Art of War Machiavelli declares, "But to prevent a militia from injuring others or overturning the laws and liberties of its country (which can only be affected by the power and ingenuity of the commander), it is necessary to take care that the commanders do not acquire too great an authority over men." 39 This does show in Machiavelli's writings a correlation between the readiness of the followers and the leader which directly relates to Hersey and Blanchard's Model of Situational Leadership. In this 
example the readiness level of the followers would be (R4) and the leader would definitely exhibit (S4) delegating characteristics (See Figure 2). In order not to acquire too much power, the leader would exemplify low relationship and low task behavior.

Niccolo Machiavelli is a political scientist. His writings, even The Art of War, are essentially focusing on political theory, leadership, and power. Through an analysis of some of his text it can be shown that he had exhibited leadership characteristics corresponding to Hersey and Blanchard's Model of Situational Leadership. It must be noted that his philosophy mainly centers on the matching (R1) and (S1) readiness level of followers and leadership style. This can be explained by the notion that Machiavelli's writings focus often on military matters which are abnormal situations where a leader does not always have the opportunity to increase his relationship behavior towards his followers.

However, two statements central to Machiavelli's overall political theory do not necessarily have to do with war. The comments relate to power and leadership. Machiavelli pondered the nature of love and fear as a leader. He stated:

Upon this a question arises: Whether it be better to be loved than feared or feared than loved? It may be answered that one should wish to be both, but, because it is difficult to unite them in one person, it is much safer to be feared than loved, when, of the two, either must be dispensed with. And that prince who, relying entirely on their promises, has neglected other precautions, is ruined; because friendships that are obtained by payments, and not by greatness or nobility of mind, may indeed be earned, but they are not secured, and in time of need can not be relied upon; and men have less scruple in offending one who is beloved than one who is feared, for love is preserved by the link of obligation which, owing to the baseness of men, is broken in every opportunity for their advantage; but fear preserves you by a dread of punishment which never fails. ${ }^{40}$ 
The above describes a leader, who through striving to be feared rather than loved, would be clearly exhibiting (S1) low relationship leadership behavior. If the followers were afraid of the leader, it would seem likely that they would be insecure or exhibit the (R1) low readiness level. In attempting to be feared rather than loved, the leader is creating an (R1) readiness level(See Figure 2). When the followers, as Machiavelli mentions, cannot be relied on, they too are at the (R1) low readiness level because they would be unable or unwilling to follow the leader. The leader, according to Machiavelli and Hersey and Blanchard, in order to be successful in accomplishing a task would have to apply (S1) telling leadership characteristics(See Figure 2).

A second phrase that Machiavelli is most known for, which applies to Hersey and Blanchard's Model of Situational Leadership is "Know when to be a fox or a lion." In The Prince Machiavelli notes:

Everyone admits how praiseworthy it is in a prince to keep faith and to live with integrity and not with craft. Nevertheless our experience has been that those princes who have done great things have held good faith of little account, and have known how to circumvent the intellect of men by craft, and in the end have overcome those who have relied on their word. You must know there are two ways of contesting, the one by the law, the other by force; the first method is proper to men, the second to beasts; but because the first is frequently not sufficient, it is necessary to have recourse to the second. Therefore, it is necessary for a prince to understand how to avail himself of the beast and the man. A Prince, therefore, being compelled knowingly to adopt the beast, ought to choose the fox and the lion; because the lion cannot defend himself against snares and the fox cannot defend himself against wolves. Therefore it is necessary to be a fox to discover the snares and a lion to terrify the wolves. ${ }^{41}$

In completing certain specific tasks the readiness level of the followers may be

(R3) moderate to high, able but unwilling. It may take the wily fox in applying (S3) 
participating leadership characteristics to achieve the task(See Figure 2). In other situations the followers may be at $(\mathrm{R} 1)$ low readiness and it may take the courage of the lion in exhibiting (S1) telling leadership characteristics in order to be successful (See Figure 2).

These two thoughts are the foundation of Machiavelli's discourses on power and leadership. The above comments, when analyzed in relation to Hersey and Blanchard embrace the Model of Situational Leadership. However, Machiavelli's texts also deal heavily with the ethics of situations.

\section{NICCOLO MACHIAVELLI AND THE ETHICS OF THE SITUATION}

In examining the ethics of the situation, the researcher may turn to Max Weber's dualistic model of the two ethics — the ethic of responsibility and the ethic of ultimate ends. The two types of ethics were value systems used to measure actions. The ethic of ultimate end was broad and exalted while the ethic of responsibility was much narrower and could be thought of as the day to day application of leadership.

Niccolo Machiavelli touched upon the ethics of the situation as he created a blueprint of action for the leaders of the Italian Renaissance. Both ethics are embedded within his teachings, however, the day to day practicalities of the ethic of responsibility is found in Machiavellis writings much more often than the loftier intent of the ethic of ultimate ends. This supports Machiavelli's catch phrase "Know when to be like a lion and when to be like a fox."

Machiavelli's writings have an element of a lofty intent. He writes, "It cannot be called talent to slay fellow-citizens, to deceive friends, to be without faith, without mercy, 
without religion, such methods may gain empire, but not glory."42 Glory not empire is valued by Machiavelli. He does not care as to how much land is acquired by a prince if glory is not part of the bargain. Glory is his overriding, lofty intent.

To achieve this glory Mahciavelli looked to the ancients. In particular he examined the Romans with their ideal of active citizenship as a means of attaining honor. Machiavelli was aware that in achieving glory and honor some could suffer. He notes:

But most marvelous of all is to observe the greatness which Rome attained after freeing itself from its kings. The reason is easy to understand; for it is not the well being of individuals that make cities great, but the well being of the community; it is beyond question that it is only in republics that the common good is looked to properly in that all that promotes it is carried out; and, however much this or that private person may be the loser on this account, there are so many who benefit thereby that the common good can be realized in spite of those few who suffer in consequence. ${ }^{43}$

Machiavelli acknowledges that in striving to attain a lofty intent in this case glory through the common good, some citizens may suffer. That however, does not necessitate that the leader cease all efforts to strive forwards glory and the common good.

As mentioned, Machiavelli writes within the context of a prevailing ethic namely the achievement of glory. However, his blueprint for leaders of the Renaissance was firmly rooted in the day to day practicalities embedded in Weber's ethic of responsibility. To attain glory was a product. The process to achieve the product necessitated that the leader take actions with an eye to the consequences. The situation and the consequences determined the leaders actions. This Model, an overriding intent to achieve glory through the application of less than lofty actions in order to achieve this end was found throughout the primary sources examined. 
When analyzing Machiavelli's works in regards to the ethics of the situation, a correlation can be drawn between his message and Weber's ethic of responsibility.

To attain glory, a general must lead an army that is united and will fight.

Machiavelli states, through the voice of Fabrizio in The Art of War:

But what most commonly keeps an army united, is the reputation of the general, that is, of his courage and good conduct; without these neither high birth nor any sort of authority is sufficient. Now the chief thing incumbent upon a general, in order to maintain his reputation is to pay well and punish soundly; for if he does not pay his men duly, he cannot punish them properly when they deserve it. ${ }^{44}$

A general must, in order to achieve glory in the end, be able to pay his men when it is necessary and inflict punishment when the situation warrants such actions. The overriding goal is glory but to achieve this, the general must be able to both reward and punish. There is no prevailing ethic but rather a leader determining pragmatically when it is appropriate to reward or punish his troops.

Glory is the goal for Michiavelli. In The Prince he writes the following about a usurper trying to achieve glory:

In seizing a state, usurper ought to examine closely into all injuries which it is necessary for him to inflict, and to them all at one stroke so as not to have to repeat them daily; and thus by not unsettling men he will be able to reassure them, and win them to himself by benefits. He who does otherwise either from timidity or evil advice is always compelled to keep the knife in his hand; neither can he rely on his subjects, nor can they attach themselves to him. For injuries ought to be done all at one time so that being tasted less, they offend less, benefit ought to be given little by little, so that the flavour of them may last longer. ${ }^{45}$

In this example, Machiavelli counsels leaders to inflict injuries quickly and with one blow so that men will not be unsettled. Machiavelli with this advice, is not as 
concerned with his overriding goal and its correlating ethic but rather, he is concerned with the consequences of the actions of a prince seizing power. This does not exhibit lofty intent but rather is simply a means to an end.

To Machiavelli the practicalities of leadership, with an eye toward glory, necessitate cruelty at times. He states, "Therefore, a prince so long as he keeps his subjects united and loyal, ought not to mind the reproach of cruelty, because with a few examples, he will be more merciful than those who, through too much mercy, allow disorders to arise, from which follow murders or robberies; for those are wont to injure the whole people, whilst those executions which originate with a prince offend the individual only. ${ }^{, 46}$ Cruelty becomes a means to an end and in fact Machiavelli notes that cruelty even makes the leader merciful in the long run. If mercy is an ultimate end then the cruelty perpetrated by the leader is actually the demonstration of the duality of Weber's Model of Two Ethics. The ethic of ultimate end is the overriding goal attained by application of the ethic of responsibility.

When Machiavelli asks "Upon this a question arises: whether it be better to be loved than feared or feared than loved." ${ }^{47}$ Machiavelli is examining the consequences of love or fear for the leader rather than determining whether or not love or fear is a lofty intent. The application of which on a daily basis will keep a prince in power.

The essence of situational leadership and ethics is applied in Machiavelli's central theme for the leader. He states, "A prince, therefore, being compelled knowingly to adopt the beast, ought to choose the fox and the lion; because the lion cannot defend himself against snares, and the fox cannot defend himself against wolves." ${ }^{, 48}$ There are times that 
a leader needs to be cunning and sly and there are occasions where it is necessary to be courageous and bold. Both are a means to an end which is the attainment of glory.

Machiavelli acknowledges that a prince must be wary of appearances. $\mathrm{He}$ comments:

For this reason a prince ought to take care that he never lets anything slip from his lips that is not replete with the above named five qualities, that he may appear to him who sees and hears him altogether merciful, faithful, humane, upright, and religious. Everyone sees what you appear to be, few really know what you are. ${ }^{49}$

The leader must appear civil even though he may be evil. The consequences of appearing otherwise may be a loss of power and glory.

The means to an end is paramount to Machiavelli. He notes, "In the sphere of politics, a good end justifies what is morally wrong" ${ }^{, 50}$ Again, Machiavelli draws a parallel to Weber's two ethics of the situation. When a leader has a lofty end as a product, the day to day process to achieve that product may at times be morally wrong.

Machiavelli found an example of this in examining the ancients. He states, "When danger was imminent, the Romans chose to appoint a dictator i.e., to give power to some one man to make decisions without consulting others and to carry them out without anyone having the right to appeal." ${ }^{51}$ The lofty intent to the Romans was the preservation of the state and the ethic of responsibility applied to achieve this was the dictatorship with its loss of personal liberty.

To Machiavelli a change in the nature of a leader to achieve an ultimate end was appropriate. He comments, "He who has at one time seemed to be good, and proposes for his own purposes to become bad, should make the change by appropriate stages, so 
adopting his conduct to circumstances that, before the change in character has robbed you of your old supporters, it may have brought you so many new ones that your power will not be lessened." ${ }^{, 52}$ Again, the application of the ethic of responsibility, the practicalities of day to day leadership, are necessary to achieve the ultimate end.

Machiavelli's ultimate end is achieving glory. He looked to the ancients as guides toward that end. He observes in his examination of Cyrus The Great, "For in view of the amount of fraud used in the first expedition of Cyrus made against the king of Armenia and of the fact that it was by means of deceit, not by means of force, that he acquired his kingdom, one cannot but conclude from such actions that a prince who wishes to do great things must learn to practice deceit. ${ }^{, 53}$ The ultimate end is power and glory the way it is achieved is through deceit. The application of deceit is an example of the day to day practicality of leadership Machiavelli drew from the ancients.

Hersey and Blanchard's Model can be applied to Machiavelli's leadership characteristics. As a leader, or an author writing about leadership, he supported the leader applying different leadership characteristics based on the readiness level of the followers in order to accomplish a specific task. The leadership of Machiavelli was embedded in the context of situational ethics for he saw that power and glory was the ultimate end of the leader. How a leader achieved that end was inconsequential, the key was the attainment of the end. Cruelty, deceit, and fraud were nothing more than a means to an end. 


\section{CHAPTER III NOTES}

${ }^{1}$ R. Ernest Dupuy and Trevor N. Dupuy, The Harper Encyclopedia of Military History (New York: Harper Collins Publishers, 1993), 434.

${ }^{2}$ Robert Ergang; The Renaissance (New York: D. Van Nostrand and Co., Inc., 1967), 6 .

${ }^{3}$ John Hale, The Civilization of Europe in the Renaissance (New York: Atheneum, 1994), 192.

${ }^{4}$ Robert Ergang, The Renaissance ( New York: D. Van Nostrand and Co., Inc., 1967), 9 .

${ }^{5}$ Ibid., 9.

${ }^{6}$ Hale, 194.

${ }^{7}$ Ibid., 197.

${ }^{8}$ Ergang, 95.

${ }^{9}$ Ibid., 81.

${ }^{10}$ Ibid., 75.

${ }^{11}$ Ibid., 76.

${ }^{12}$ Hale, 509.

${ }^{13}$ Ergang, 51.

${ }^{14}$ Ibid., 61.

${ }^{15}$ Hale, 171. 
${ }^{16}$ Ibid., 267.

${ }^{17}$ Ergang, 74.

${ }^{18}$ Ibid., 87.

${ }^{19}$ Dupuy and Dupuy, 532.

${ }^{20}$ Ibid., 466.

${ }^{21}$ Ibid., 466.

${ }^{22}$ Ibid., 466.

${ }^{23}$ Ibid., 467.

${ }^{24}$ Ibid., 467.

${ }^{25}$ Niccolo Machiavelli, The Art of War, trans. Ellis Farneworth, with a foreword by Neal Wood (New York: De Capo Press, Inc., 1965), xlvi.

${ }^{26}$ Leo Strauss, Thoughts on Machiavelli (Chicago: The University of Chicago Press, 1984), 54-55.

${ }^{27}$ Ibid., 83-84.

${ }^{28}$ Ibid., 133.

${ }^{29}$ Ibid., 173.

${ }^{30}$ Machiavelli, 29-30.

${ }^{31}$ Ibid., 127

${ }^{32}$ Niccolo Machiavelli, The Discourses, edited and with a Foreword by Bernard Crick (New York: Penguin Books, 1983), 184. 
${ }^{33}$ Ibid., 190.

${ }^{34}$ Ibid., 195.

${ }^{35}$ Ibid., 195.

${ }^{36}$ Ibid., 247.

${ }^{37}$ Machiavelli, 31.

${ }^{38}$ Ibid., 33-34.

${ }^{39}$ Ibid., 41.

${ }^{40}$ Niccolo Machiavelli, The Prince, trans. W. K. Marriott (Chicago: Encyclopedia Brittanica, Inc., 1952), 24.

${ }^{41}$ Ibid., 25.

${ }^{42}$ Machiavelli, The Prince, 12.

${ }^{43}$ Machiavelli, The Discourses, 275.

${ }^{44}$ Machiavelli, The Art of War, 175.

${ }^{45}$ Machiavelli, The Prince, 14.

${ }^{46}$ Ibid., 23.

${ }^{47}$ Ibid., 25.

${ }^{48}$ Ibid., 25.

${ }^{49}$ Ibid., 25.

${ }^{50}$ Machiavelli, The Discourses, 63.

${ }^{51}$ Ibid., 190. 


\section{CHAPTER IV}

\section{NAPOLEON BONAPARTE}

\section{HISTORICAL BACKGROUND}

To understand the relationship between the leadership style and the situational ethics exhibited by Napoleon Bonaparte and the characteristics of Hersey and Blanchard's Model of Situational Leadership the researcher must examine the historical context of the era in which Bonaparte lived. The historical situation of France in the late eighteenth and early nineteenth century, including the socio-economic, political, and military conditions of the era, will be analyzed in order to comprehend possible motives for Napoleon Bonaparte's leadership style and ethical choices.

To analyze the historical context of Napoleon Bonaparte, the researcher must begin with the French Revolution. Napoleon's rise to power and subsequent fall was directly tied to the French Revolution. Without the Revolution there might not have been a Napoleon.

The Revolution came to a country that was seemingly at the zenith of its power. According to Andre Maurois:

In 1788 France was still the most powerful state in Europe, with a population of twenty-six million at a time when Great Britain had barely twelve million and Prussia eight. She had just won the American War; her military and naval prestige had never stood higher - the victories of the revolutionary armies would be due not only to the fine energy of the 
Committee of Public Safety, but to the nation's latent power and to the tools of war inherited from the ancient regime. ${ }^{1}$

France's navy and army had several of the powerful European nations - Great Britain, Austria, and Prussia. France's reputation was at its apex on the continent and abroad. Andre Maurois further states:

Thus no one could have justly said that the French monarchy in 1789 had come to grief abroad. At home, was the monarchy oppressing the country? By law it remained absolute, in actuality, the liberals had held power for fifteen years. Yet France boiled with unrest and her government had lost its reputation. ${ }^{2}$

France was militarily supreme but it was a country seething with turmoil in 1789 .

The indebtedness incurred through years of war, class strife, and inequities in taxing policies had led to this situation. King Louis XVI called the Estates-General which had last met in 1614 in order to raise additional taxes. The Estates-general was composed of representatives of the three orders of French society in 1789. The First Estate, the clergy, had 130,000 members; the Second Estate, the nobility, had 400,000 members; and the Third Estate, included everyone else. The French Revolution, while directly initiated by national indebtedness and taxation, was basically an attempt by the Third Estate to gain political power and social acceptance. The Third Estate took the lead and constituted itself as a national assembly.

The goal of the Revolution at its onset was not the removal of the king. In fact according to Andre Maurois:

As for the French, few among them in 1789 wished for a constitutional monarchy of the Anglo-Saxon sort. The king, they thought, should hold his privileged ones in check and public opinion should hold the king in check. $^{3}$ 
At the beginning of the French Revolution, the intent was to retain the king but to render the monarch into a constitutional head-of-state. In addition, the king would be forced to keep the privileged First and Second Estates under control. At the onset of the Revolution little thought was given toward the removal of the king. The French people still wanted a king, at least in 1789 , but one whose powers were no longer absolute.

During the course of The Revolution, the government went through a series of reformations such as The National Assembly, the Committee for Public Safety, the Convention, and the Directory. By 1792, the government passed into the control of Maximillen Robespierre who appointed the Committee for Public Safety. In 1793 the Committee began the terror in which thousands, including the king and queen, were guillotined as enemies of the state and to reinforce Robespierre's dictatorship. The terror finally ended in 1794 when Robespierre himself was executed. Power shifted from the Committee for Public Safety to a new government body called the Convention. This body, when confronted by a royalist uprising in 1795 , called upon a young artillery officer named Napoleon Bonaparte to come to its defense. This event was pivotal in the rise of Napoleon. Will and Ariel Durant note regarding this incident:

Then, in one of those whims of history that open a door to the inevitable, the Convention, besieged (October 5,1795 ) by royalists and others, assigned Barras to organize its defense. He decided that a blast of artillery would do it, but no artillery was at hand. He noted Napoleon's enterprise at Toulon; he sent for him, commissioned him to secure and use artillery; it was done, and Napoleon became at once famous and infamous. ${ }^{4}$

With a blast from his guns during a Revolutionary battle, Napoleon secured a future which would lead him to incredible heights and a dramatic downfall. The Convention was 
dissolved and replaced by a five man governing body known as the Directory. The Directory was eventually dissolved in 1799 during Napoleon's coup detat.

As the Old Regime, destroyed by the Revolution, transitioned into the Napoleonic Age there were some dominant socio-economic trends. Louis Bergeron notes, "It was in fact landed property, in the last analysis, that was officially recognized as the foundation that included not only the elite expressly distinguished as such by the Napoleonic regime, but also those of the Old Regime, and more generally a large fraction of citizens whose status as property owners attached them to public order." Not only did landed property owners form the foundation of the economy in Napoleonic France but they also constituted a growing segment of society. In the Revolution, as property was confiscated from the clergy and nobility much of it fell to the Third Estate. Thus the agricultural strata of France grew at the expense of industry. Rather than moving from the farm to the cities to seek employment, which was occurring in Great Britain at this time, French men and women were attracted to the new agricultural opportunities to be found on land made available by the Revolution. This land was still subject to taxation. As Napoleon rose to power, taxes on this property formed the basis of the French economy. As a leader Napoleon used this class to support his government. Louis Bergeron states:

Bonaparte preserved intact the fiscal inheritance from the governments of the Revolution, that is, a system of direct taxation. The tax on real estate, first of all, provided almost three fourths of the government's resources from direct taxes. ${ }^{6}$

Napoleon used these resources and the sons provided by these farmers to feed his wars of conquest. In fact Napoleon based the greatness of a nation upon the population. Bergeron 
notes:

Napoleon Bonaparte identified an abundance of men with the grandeur, prosperity, and happiness of the nation. But this official populationism was less and less in accord with the realities of the early nineteenth century when J. B. Say was spreading the idea of Malthus: "People should be encouraged to have savings rather than children..." While the total population of France between 1789 and 1815 rose from somewhat over twenty-eight to somewhat over thirty million inhabitants, its share in the population of Europe (without Russia) fell from twenty-five percent (at the end of the reign of Louis XIV) to only about twenty percent in $1815^{\text {? }}$

The French Revolution and Napoleon unleashed a great wave of French

Nationalism - love of country, - "Liberty, equality, and fraternity." Napoleon, as a leader, used this spirit of nationalism to infuse his armies with a nationalistic spirit which some of the other armies lacked.

The sons of France that were so important to Napoleon were killed off in large numbers in his many wars of conquest. As noted above France's share of the European population declined partly because of the constant Napoleonic warfare. This had an effect on war itself but also on society and the economy. As men died there were fewer hands to help on the farms and in what industry was in existence in cities and towns. In addition, as fewer citizens were available as volunteers for the army, conscription became a necessity. The issue of conscription and the negative emotional effect it had on the population was one issue which eventually led to Napoleon's first abdication in 1814 .

However, even though war was a drain on manpower and therefore effected society and the economy, it also had positive effects on the economy. Will and Ariel Durant state:

His greatest success as an administrator was in finance. Strange to say, his 
wars, till 1812 , usually brought in more than they cost; he put upon his enemies the onus of beginning the action; and when he defeated them he charged high fees - and Old Masters for the lesson. ${ }^{8}$

In many instances the frequent wars that Napoleon fought added to the coffers of France. Napoleon did not use this added money to spur on capitalism. The Durant's remark:

Napoleon himself was not very fond of capitalism. He encouraged French commerce by the multiplication and maintenance of all avenues of transport and trade and by the supply and steadiness of money; but he discouraged it by the thousand and one regulations of the Continental Blockade. ${ }^{9}$

Napoleon established the Continental Blockade to combat the pressure put on him by Great Britain. France was the dominant land power on the European continent with no equal but she could not conquer Great Britain because of Britain's powerful navy.

Napoleon hoped to offset British power by closing all European ports to British shipping. As mentioned, this had a detrimental effect on the French economy as well and therefore wasn't extremely successful. As a leader Napoleon's Continental Blockade was a misguided policy.

France was a society that had transformed itself from a framework whereby the First and Second Estates ruled in conjunction with an absolute monarchy to one in which power shifted to the Third Estate. In the rise of Napoleon, a form of absolute imperial had re-surfaced. He created a new aristocracy, the Napoleonic elite, who owed their positions to him - an important feature of his leadership style. The leadership of Napoleon Bonaparte and the policies of that leadership did not cause societal or economic advantages to France in the long run. 
Politically, in the waning days of the French Revolution, anarchy was running rampant. Napoleon had been called upon to defend the Convention in Paris during the October, 1795 , royalist uprising. This action led to Napoleon being placed by the Directory in command of the Army of Italy, whose purpose was to invade and conquer Northern Italy, a province of France's hated enemy Austria. After successes in Italy, the Directory sent Napoleon to Egypt with the dual purpose of severing British lines of communication to her colonies in India and with the more important intent of keeping the rising star of Napoleon away from Paris. Napoleon abandoned his army in Egypt, after winning several land battles, because of the political machinations against him back in Paris. Napoleon as a leader was able to emphasize his victories in Italy and to minimize his defeats in Egypt. This is another aspect of his leadership. The members of the Directory were fearful of the public approval that Napoleon's string of military victories were bringing to him. Once reaching Paris, Napoleon wrested power away from the Directory in a coup. Louis Bergeron mentions the following regarding the coup:

The very principle of the coup detat was to put an end to what he called "anarchy" - that is, the danger of a royalist counter revolution and of a renewal of Jacobinism or Bourbonism. Stabilization could come only with an authoritarian Republic. ${ }^{10}$

Napoleon, while leading the army in Egypt, saw a state of disorder developing back in France. The coup that he directed on November 9, 1799, was meant to stabilize the situation. In essence, Napoleon became the dictator of France by naming himself First Consul. Napoleon represented the strong man on horseback who promised stability, order, and greatness - all important points in his leadership style. 
Following the coup detat, Napoleon moved to consolidate his political situation.

He clamped down on criticism. Bergeron states:

Silence was to be imposed on the factions and trouble makers on both sides. Hence no opportunity should be left for the expression of political differences, either in parliamentary debate or through the medium of the press. ${ }^{11}$

Open debate ceased to exist in Napoleonic France. The forum for public criticism the parliament or the press was swiftly removed. Suppression of critics was an important part of his leadership style. Bergeron goes on to mention the following regarding Napoleon and the press:

As for liberty, there is no doubt that Napoleon considered freedom of the press a public scourge. The press existed in his eyes only for service to the State and as an instrument of propaganda. ${ }^{12}$

Napoleon valued the press but mostly for use as a propaganda tool in his wars. He valued the press for the promotion of his policies and personality. It was a major tool in affirming his leadership.

As dictator, Napoleon acted similarly to his role as a general -- he took over direct control of many functions for the operation of the state. He presided over the jurists who developed a new civil code which unified France's laws, he centralized education so that it resembled the training of an army, and he created the Legion of Honor which was a tool to keep men busy reflecting on precedence and etiquette rather than criticizing the government.

From the moment Napoleon seized political power, he concerned himself with retaining it. Andre Maurois stated: 
To the last, he must please the French, and Bonaparte always believed that they preferred glory to freedom. "The Republic? It's a will-o-the-wisp with which the French became infatuated, but which will pass away like so many others They require glory, the satisfaction of their vanity, but about freedom they know nothing." 13

Napoleon hoped to keep the people of France supportive through victories and he hoped to keep his soldiers loyal through pomp, ceremony, and the awarding of medals. But even beyond the glories of victory, Napoleon felt that power would be kept through more than just victories.

According to Louis Bergeron, "Napoleon always felt that his popularity rested not only on military victory but on the abundance and low price of bread." ${ }^{\text {14 }}$ As long as he could continue to provide military victories and cheap bread, Napoleon believed that he would remain in power. His control rested partly on an economic base.

Even before Napoleon had become the dictator, the situation was militarily grave for France. Once the King and Queen of France had been executed as part of the Terror, all of Europe grew tense. Maurois states, "Europe alarmed by the theory of natural frontiers and the wars of propaganda, seized the excuse, supplied by this heinous crime (the Killing of the King) to unite against France. ${ }^{15}$ As Napoleon became the First Consul, all of Europe was pounding at the gates of France.

Napoleon used the theme of a common enemy to rally support! The French were mobilized under Napoleon in what appeared to be self defense of their country. This self defense then became offensive and was carried to invasions of other countries. As a leadership characteristic - the best defense is an offense. 
When Napoleon assumed the dictatorship in 1799 , his first response was not military adventurism but rather stabilization. According to Maurois, "But what the country expected above all from the First Consul was peace abroad; he himself wanted it because it alone would allow him to continue his task of internal pacification, because he knew that one single defeat would suffice to overthrow a regime as new as his and finally because, as a coup detat general, he feared similar adventures on the part of other generals. $" 16$ It would take time for Napoleon to consolidate his new political and military power. His initial grasp on power was fragile.

As 1800 dawned, Napoleon was faced by offensive action from the Austrians. In Italy, at Marengo, Napoleon, who was actually saved by his generals Desaix and Kellerman, crushed the Austrians. In 1802, the Peace of Amiens was signed between Britain and France which brought an armed truce to Europe for the first time in ten years. It was short lived, for in 1803 war once again broke out between Great Britain and France. In 1804, Napoleon was made Emperor of the French and further developed plans for the invasion of Britain. Being made emperor was a key point in his leadership. $\mathrm{He}$ crowned himself, which meant he owed his power to Napoleon. His fleet was defeated at Trafalgar in 1805 and hopes of the invasion of Britain were dashed. Napoleon then turned his eyes toward Austria and Russia. They had joined in an alliance with Britain to fight against France. Napoleon completed a brilliant campaign which culminated in a victory over the combined armies of Austria and Russia at Austerliz in December, 1805. This was the zenith of imperial France and of Napoleon Bonaparte. France and Napoleon would never again in this period hold the social, political, and military power that was 
achieved in December of 1805.

Napoleon's constant nemesis throughout his reign was Great Britain. Britain's strategy against France and other continental powers was always the same -- use the British Navy to capture an enemy's colonies and disrupt communication routes, use the small but well disciplined British Army to fight on the periphery of the opponents land, and pay subsidies to other nations to fight against that common enemy. Britain used all of these strategies in their wars against France.

Great Britain always pursued a policy that Belgium should be neutral or friendly to England. Belgium's coastal location made it a threat to Great Britain, should it be occupied by an unfriendly power.

France had conquered Belgium which had been a part of the Austrian Empire. France wished to include Belgium as part of France but Britain had a long standing relationship with Belgium which opposed her absorbing Belgium. Napoleon had a plan to force Britain to allow this. According to Maurois:

In order to force the British to do so, Bonaparte dreamed of setting up a "Continental Blockade" which would close the European Markets to the English Merchants. The only trouble was that for this policy to succeed, it was necessary that all the ports of Europe be closed - there could be no Continental Blockade without a Continental Empire. ${ }^{17}$

Napoleon felt that the only country that stood in his path towards European domination was Great Britain and the best way to bring Britain to her knees was through a disruption of her commerce. Creating a continental empire, led by France, would allow Napoleon to accomplish this. From 1805 to 1812 , he sought to do this. His goal was also to create a partnership with the vast Russian Empire but when she refused to join in his empire 
Napoleon decided to invade. His 1812 campaign into Russian which climaxed with the destruction of the Grand Army was the death knell of Napoleonic France. However, the Russian campaign was not the first crack in Napoleon's continental empire. Napoleon had over-extended himself; he structured his resources too far and thus jeopardized his power base. This was a consideration of his leadership.

In 1807, Great Britain stood alone against France. Portugal, on the Iberian Peninsula, still continued to trade with Britain, which was a direct violation of the trade embargo that France had established in the continental system. Under the pretext that they were guarding the Spanish coast, the French invaded Spain in 1807. King Charles IV was removed from the throne and in his place Napoleon's brother, Joseph, was crowned. This led to a Spanish revolt. The Peninsular War broke out and was fought on the Iberian Peninsula from 1807 until 1814. Great Britain had been looking for a crack in the French armor for a long time and the Peninsular War allowed them to support the Spanish and Portuguese monetarily and militarily and bleed the French dry. The Peninsular War, in conjunction with the failed Russian invasion of 1812 , led to the first abdication of Napoleon in 1814. The Spanish War was Napoleon's Vietnam. He was engaged militarily in too many places at the same time. What does this say about his leadership?

Napoleon attempted a comeback in 1815 after he had been exiled to Elba. At Waterloo in June of 1815, the French met the combined British and Prussian armies under Wellington and Blucher. Through miscalculation and poor generalship from his subordinates, Napoleon suffered a final defeat. He was exiled to St. Helena and died there in 1821 . 
Wars in the eighteenth century were fought primarily over dynastic issues or claims to small portions of territory. The flintlock musket was the weapon used on land and the rate of fire of this musket caused infantry lines to shrink from six men deep at the turn of the century to three and even two. Because of the rigidity of the formations and the rate of fire of the weapons, discipline among the ranks was high and severe. Control and maneuver was the primary emphasis of military leaders both on land and sea.

Throughout this century and in all of the frequent European wars, the same rigid, close ordered, defensive tactics were embraced by many. However, France began to experiment with more offensive, open order tactics.

In 1789, when the French Revolution began, most of the European powers had not altered their system of military tactics. France did. As the Dupuys state, "The introduction of the so-called attack column as a standard combat formation in the wars of the French Revolution was in part of a result of tactical experimentation begun by Marshal Saxe in the middle of the previous century, and in part a natural formation adopted to make the maximum use of the poorly trained hordes produced by the levee en masse, troops that lacked the training and discipline to stand and fight in the linear system of Frederick."18 When the French Revolution began many of the officers, who were of the Second Estate, were executed or emigrated. The leadership of the military was wiped out. In addition as many of the nations of Europe gathered in an alliance after the execution of Louis XVI and Marie Antoinette, France enacted the Levee en masse, a national conscription. Many of the able bodied men of France were brought into service and were rushed to the various fronts to protect France and the Revolution. There was not time or the resources 
to build highly disciplined and trained armies to fight the invaders of France. Therefore, the Revolutionary armies wholeheartedly embraced the tactics of Marshal Saxe.

On land the new tactics of Revolutionary armies were twofold:

1. Attack columns were utilized whereby a column would be organized that would be narrower at the front and much greater in depth than the opposing formation.

2. Light infantrymen would be organized in small bands that would act separately from the attack columns. Their purpose would be to screen movements of the columns and to engage the enemy whenever possible.

The attack columns were revolutionary and gave a tremendous advantage to the

French armies. According to Ernest and Trevor Dupuy:

The great tactical value of the column lay in its flexibility and versatility. It permitted the commander to move large numbers of men over the battlefield with better control and far more rapidly than had been possible before. $^{19}$

French generals had an overwhelming advantage with the attack columns over their adversaries in the two most important factors on the battlefield - maneuver and control.

The light infantry of France was also an advantage. The Dupuys comment:

In their political implications, the new light-infantry tactics were revolutionary. Both the French Revolutionary armies and the British System abandoned the brutal and degrading discipline of the eighteenth century armies. The light infantry men fighting often as a relatively autonomous individual in small formations in open order, was much less under the direct supervision of his officers. Brutal treatment and close control gave way to appeals to regimental pride, revolutionary élan, and the spirit of nationalism. ${ }^{20}$

Many of the elements of the French Revolution were embodied in these new and revolutionary military tactics. 
Napoleon Bonaparte used the new tactics plus added some refinements of his

own. As a leader, Napoleon was eager to use innovative methods that challenged traditional ones. Artillery was an important arm of the Napoleonic armies. The French artillery outclassed that of their opponents for most of this period. The Dupuys note:

The main feature of this artillery was mobility, obtained by reducing the length and weight of the barrel and the weight of the gun carriage; the latter was also provided with iron axletrees and wheels of large diameter. Napoleon took full advantage of the maneuverability of the French artillery and made out of it the most important tool of his warfare. One of this favorite techniques, particularly employed in later years as the quality of his troops declined, was employment of the grande batterie, physically massing a preponderance of artillery fire in support of his main effort on the battlefield, literally blasting the enemy line to shreds to permit his infantry to advance. ${ }^{21}$

Finally, on the battlefield, Napoleon employed cavalry. Primarily, cavalry with the support of horse artillery would be utilized against the opponents' infantry that had been shaken and demoralized by the massive artillery bombardment. Napoleon's combination of attack columns, light-infantry, massed artillery, and cavalry utilized in an organized systematic fashion left him victorious on most of the battlefields of the era.

Napoleon's campaign planning, which led to the struggle on the battlefield was coldly calculated. Napoleon attempted to develop a campaign so that he would be victorious before a battle was even fought. He tried at every opportunity to rapidly march around the enemy's flank, cut the opponents line of communication, and then force the enemy to fight at a disadvantage. Each campaign was different. Ernest and Trevor Dupuy state, "Napoleon avoided stereotypes and attempted to develop his plans for every campaign and every battle in such a way that his enemies could never know what to expect of him.,"22 
As Napoleon's troops moved, they lived off of the land whether it be territory of friend or foe. Four day emergency rations were carried by supply columns following the troops but living off of the land, allowed Napoleon the rapidity necessary for his system of warfare.

Napoleon never tried to occupy the strategic and political centers of his opponents until the armed forces of the enemy had been destroyed on the battlefield.

The French Revolution unleashed the forces of nationalism which turned the socio-economic, political, and military framework of eighteenth century Europe upside down. Napoleon Bonaparte appeared on the scene and used these nationalistic forces in calculating fashion to conquer most of Europe and established a continental system which at its height dominated all of Europe except for Great Britain.

\section{WRITINGS OF NAPOLEON BONAPARTE}

The primary sources used to analyze whether or not Napoleon Bonaparte embraced the characteristics of both Hersey and Blanchard's Model of Situational Leadership and Situational ethics are Napoleon's Letters translated and edited by J. M. Thompson and The Mind of Napoleon translated and edited by J. Christopher Herold. Each of these primary sources used are compilations of material written or dictated by Napoleon Bonaparte.

These texts were selected for this analysis because they contain the written word of Napoleon. Being a man of action, Napoleon rarely found the opportunity to record his thoughts in an organized, systematic text. Through an analysis of his letters and communiqués the researcher can begin to develop a picture of Napoleon's leadership 
characteristics. The editor's purpose with each of these texts was to provide an illustration of the many facets of Napoleon's character.

Both books are organized in some type of systematic fashion. Napoleon's Letters is a compilation of Napoleon's correspondence organized chronologically beginning with a letter written on June 25,1784 , to his uncle and culminating on July 14,1815 , with a letter to the Prince Regent regarding Themistocles. The editors' purpose was to use the letters which dealt with subjects as varied as the history of Corsica, making war pay, the invasion of England, Joan of Arc, the new nobility, beet sugar, and economy and try to create the illustration of a man of action using his actual words.

Herold's The Mind of Napoleon somewhat differed as a primary source. Herold's purpose in selecting these words of Napoleon was to provide an insight into the mind of a man combined a high level of both the energy of thought and action. The text is divided into thirteen sections, each containing spoken and written words organized thematically. Herold's organizational themes were: the human + heart; questions of life, destiny, and greatness; the conquest of history; the political order; law and social order; church, school, and press; science and the arts; the art of ruling; nations and peoples; the art of war; projects and prophecies; the tyrant speaks; and Napoleon surveys his career.

Unlike Julius Caesar and Niccolo Machiavelli, Napoleon Bonaparte never wrote a book which could be utilized by the researcher to determine leadership qualities from the words of the author. Using the compilations edited by Thompson and Herold and focusing on the excerpts that were actually written by Napoleon Bonaparte does provide a comprehensive and thematic primary source background for this dissertation. 


\section{NAPOLEON BONAPARTE AS A SITUATIONAL LEADER}

To determine whether Napoleon, like Caesar appears to embrace or reject the leadership style characteristics found in Hersey and Blanchard's Model, the researcher examined the primary sources of Napoleon Bonaparte.

The leadership style utilized by Julius Caesar appropriately matched the readiness level of his followers. By analyzing the excerpts from the writing of Napoleon Bonaparte, whether or not he too appropriately matched styles will be established.

In addition, the situational ethics applied by Napoleon in his written word will be examined. Throughout the primary source material analyzed an emphasis on the ethics of the situation is found.

Throughout both primary sources utilized evidence of a match between the (R1) and (S1) readiness level and leadership style can be found. In a transcript of a speech before the Conseil d'Etat in 1804 Napoleon said, "We are here to guide public opinion, not to discuss it. ${ }^{, 23}$ Clearly Napoleon was exhibiting the (S1) telling leadership style. He was concerned about public opinion for he knew that his power was based on it but as a dictator and general he created public opinion and propaganda to accomplish his objectives. Napoleon's standard of operation was to either mold and bend public opinion to his way of thinking or to attempt to distract the populace in some fashion so that he could still achieve his goals. According to Hersey and Blanchard, a leader is effective when he matches the (S1) leadership style to an (R1) readiness level of the followers. In this example the followers, the people of France, were unable, unwilling, or insecure at least in Napoleon's mind. In fact his followers, at least according to his perspective were 
of two sorts. If they were good and decent, he felt that they must be persuaded to accomplish a task and if they were merely rabble, they must be led through terror. Napoleon realized that his constant wars were a drain on France in terms of money and men but he felt that through coercion or terror he could make his followers do whatever he asked in order to accomplish a task - in his case a continental empire (See Figure 3).

Napoleon's family were also his followers. He placed many members of his family on the thrones of Europe. As a leader here to Napoleon exhibited the (S1) leadership style - telling. In a letter to his brother Joseph, King of Naples, in 1806 he said, "If you do not make yourself feared from the start, you will come to grief." 24 When Joseph was installed as the king of Naples following the conquest of that kingdom, he did not immediately intimidate the populace through terror. Utilizing Hersey and Blanchard's Model, Joseph exemplified an (R1) readiness level as one of Napoleon's followers because he was unable, unwilling, or insecure about employing terror tactics to gain control of Naples which was the specific task that Napoleon wanted to complete. Therefore, using the model, Napoleon applied an (S1) telling leadership style in his letter to Joseph (See Figure 3). The letter illustrated a high task, the consolidation of a conquest, and a low relationship behavior. Napoleon was telling Joseph what to do, where to do it, and how to do it.

Another family member, Jerome, was placed on the throne of Westphalia. In 1808, Napoleon sent a letter to Jerome which stated:

There are three thing I commend to you.

1. Respect, gratitude, and loyalty to me and to the French people, to whom you owe everything. 


\section{NAPOLEON BONAPARTE}

LEADERSHIP STYLES

\begin{tabular}{|c|c|}
\hline S3 & S2 \\
\hline S4 & $\begin{array}{l}. \mathrm{A} \\
. \mathrm{B} \\
. \mathrm{C} \\
. \mathrm{D} \\
. \mathrm{E} \\
. \mathrm{F} \\
. \mathrm{G}\end{array}$ \\
\hline
\end{tabular}

\section{READINESS LEVEL OF FOLLOWERS}

\begin{tabular}{l|l|l|ll}
$\mathbf{R 4}$ & $\mathbf{R 3}$ & $\mathbf{R 2}$ & $\mathbf{R 1}$ \\
\hline & & & .A &. $\mathrm{F}$ \\
& & & . &. $\mathrm{G}$ \\
& & & .C & \\
& & & .D & \\
& & & .E &
\end{tabular}

Situation $\mathrm{A}=. \mathrm{A} \quad$ Guide public opinion, not discuss it

Situation $\mathrm{C}=. \mathrm{C} \quad$ Letter to Jerome on how to govern Westphalia 
2. Strictest economy, so as to bring out the contrast between the miserable conditions that are weighing down your subjects and unbridled luxury and waste.

3. Finally, use your time to learn what you do not know -- cavalry, infantry, and artillery tactics and the administration of justice and finance. ${ }^{25}$

An (S1) telling leadership style provides a high amount of guidance but little supporting behavior. In the above excerpt from the letter to Jerome, Napoleon did provide a high amount of guidance by specifically telling Jerome exactly what he must do to maintain the kingdom. Absent from the message was any evidence of supporting behavior. Obviously Napoleon considered Jerome unable, unwilling, or insecure in ruling Westphalia (See Figure 3).

In dealing with his family Napoleon occasionally felt that he was delegating authority which would be an example of an (S4) delegating leadership style but with closer inspection of the words of Napoleon the opposite becomes evident. Eugene, his stepson, was made Viceroy of Italy. In 1805, Napoleon sent a letter to Eugene explaining his powers and duties. An excerpt from this letter reads:

The public decree that I have signed defines the powers I am delegating to you. I am reserving for myself the most important of all - the power of directing your operations. Send me an account of your doings everyday. It is only be degrees that you will come to understand how I look at everything. ${ }^{26}$

Napoleon considers Eugene unable at this point to rule as the Viceroy of Italy without a daily connection (See Figure 3). At this point, in June of 1805, while Napoleon says that he is delegating authority to Eugene he is in fact telling him what to do in order to accomplish the specific task which is to rule and control Italy. If the leader wants to make 
sure that the Italian Peninsula is under control and the follower is unable to accomplish that task it would be most appropriate, according to Hersey and Blanchard, for the leader to tell the follower exactly what to do. Napoleon did this in his correspondence but he also mentioned that as Eugene became more willing, confident, able, and competent the possibility of a full delegation of authority could occur. If this happened it would be an example of an appropriate match of an (R4) high readiness level of the follower to an (S4) delegating leadership style.

Louis, Napoleon's brother, was installed as the King of Holland. While King, Louis re-established the Dutch nobility which had been dissolved when Holland was absorbed by the French. Napoleon had given his follower, Louis, a specific task - hold Holland for the French. Re-establishing the nobility was not part of Napoleon's grand scheme because he feared that a reinvigorated nobility could possibly lead to revolt. In fact he was afraid that Louis was beginning to become more influenced by the Dutch nobility than his own brother. On April 4, 1807, he wrote the following regarding the Dutch nobility, "Unless you retract this measure, look out for the consequences."27 Louis, the follower of Napoleon, was at the (R1) readiness level regarding his assigned task, the control of Holland as part of the French sphere of influence. He was insecure regarding the Dutch nobility. Louis wanted to please the Dutch but he feared his brother. Napoleon swiftly applied the appropriate leadership response according to Hersey and Blanchard's Model. Napoleon told Louis exactly what to do, retract his announcement and if he didn't, there would be consequences. This is a perfect example of an (S1) telling leadership style which is appropriate when the readiness level of the followers could be classified as insecure (See Figure 3). 
Napoleon loved his family and believed that it was his duty and responsibility to provide for his family. He did this by putting many of them on the thrones of Europe. While he seemingly delegated authority to each, he gave them specific instructions as to how they were to rule. Towards his family, while he may have loved them, in regards to accomplishing his tasks, Napoleon exhibited a telling leadership style.

Napoleon's marshals, eighteen of the highest ranking generals of the French Army, were almost as loved as his family members but here as well Napoleon matched an (S1) telling leadership style to what he perceived as an (R1) readiness level of his followers. Marshal Berthier was one of Napoleon's best generals. Marshall Berthier was a fifty year old general with a penchant for affairs. Napoleon's marshals had specific tasks, war. Napoleon did not feel that Berthier was able or even willing to complete this task which would entail leading armies if the general's attentions were directed towards a love affair. He wanted Berthier to get married. In a letter dated April 1, 1806, Napoleon wrote, "I want you to get married, then if you don't, I will never see you again." 28 If the marshal were concerned with his love affair as opposed to his troops, Napoleon considered him an unable or unwilling follower or an (R1) readiness level. The appropriate leadership style match would be an (S1) telling leadership style. The above excerpt from the letter that Napoleon wrote to Marshal Berthier is an example of telling behavior because Napoleon tells the Marshal to stop falling into affairs, settle down, and get married (See Figure 3). Napoleon let his marshals know where their power came from. At the same time, he informed them that while he might have delegated authority all true decision making emanated from him. During the Peninsular War, Napoleon wrote to Marshal Soult: 
How could you have forgotten that the power you exercised over the Portuguese sprang from the command I entrusted to you, and not from the play of passions and intrigue? How could a man of your ability have supposed that I should ever allow you to exercise any authority not derived from me? ? $^{29}$

Napoleon had given Marshal Soult the responsibility of commanding in the Portuguese Theatre but he was unable to maintain control. In fact, Napoleon felt that Soult was beginning to vary from his specific instructions thus causing him to send the above message. Napoleon employed (S1) leadership traits to the (R1) low readiness level of his follower, Marshal Soult (See Figure 3).

As dictator, emperor, and general, Napoleon exhibited a cold, calculating genius. He was a man who thrived on planning and detail. He left nothing to chance. Being of that makeup, he was compelled to desire control of every last detail. He did not share his grand design with others. His followers never fully understood his actions or his ultimate end. Because of this, his followers never were quite ready for autonomous leadership. Napoleon never prepared his subordinates for any assumption of duties. The leadership characteristics that he tended to employ were of the (S1) telling style which according to Hersey and Blanchard would be appropriate for followers who were unable, unwilling, or insecure in completing a task. In Napoleon's view for every situation his followers were at the same low readiness level. He employed the appropriate leadership style. However, situations change and Napoleon's eventual downfall possibly could be related to the fact that he never fully prepared any of his followers to better complete tasks nor did he carefully analyze the characteristics to determine if they could have been considered more able and competent to complete certain tasks. Napoleon wanted to control all of the 
details. To do this he had to be able to control his generals and the people he put on the thrones of the territories that he conquered. The foundation of Napoleon's control of detail was his calculating mind. To be in control he had to be able to tell rather than delegate or allow for participatory leadership. This calculating mind which strove to control all details also touched upon the ethics of situations.

\section{NAPOLEON BONAPARTE AND THE ETHICS OF THE SITUATION}

Weber's ethic of ultimate ends can be thought of as the overall framework by which a leader makes decisions to influence followers. The opposing ethic of responsibility then becomes the day to day activities of leadership enacted to achieve that ultimate end. In the primary sources utilized in this research are found examples of Napoleon's ultimate end - glory!

Following the coup detat in 1799, Napoleon wrote a letter to Citizen Beytz. In it he said:

That is the aim of all my efforts. It is upon which is centered, from this moment, the regard of all thoughtful men, the esteem of the people, and the hope of glory. ${ }^{30}$

In writing a letter to the British King, trying to coax a treaty of peace, Napoleon highlights his thirst for glory. A letter was written in 1804, addressed to General Lauriston. In it Napoleon made this comment, "Death is nothing; but to live defeated and without glory is to die everyday. ${ }^{, 31}$ Soon after Napoleon's death on St. Helena in 1821 a piece of paper was found which read in part, "The love of glory is like the bridge that Satan built across Chaos to pass from Hell to Paradise: glory links the past with the future from across a bottomless abyss. ${ }^{, 32}$ Napoleon's ultimate end, his overriding purpose was 
to achieve glory. Even as he lay dying on St. Helena, glory would insure that his name would be remembered. Napoleon did not want to be forgotten, he wanted his name to be written in the histories of France.

Glory could be achieved through battlefield heroics, stirring tales of deeds of valor, and the captured weapons and battle flags of the conquered foe. These all would lead to Napoleon's ultimate end, the vision that he had in mind as he made his incessant calculations and manipulations, a glorious end. However, when examining evidence of the day to day acts of leadership, the ethic of responsibility, acted upon in order to achieve the ultimate end, the research illustrates cold, harsh acts of cruelty.

Early in his career Napoleon was placed in command of the army marching into Italy. On June1, 1796, Napoleon wrote a letter to the Directory describing what actions he took to put down a revolt in Pavia. He said:

I had the village set on fire immediately. The step was necessary, but the sight was none the less distressing, and I was painfully affected by it. ${ }^{33}$

Napoleon wrote a letter to the Prince of Neuchatel on May 7, 1813. The purpose was to give instructions as to what should be done to punish the citizens of Hamburg for establishing a representative government. Napoleon wrote:

He is to arrest summarily all citizens of Hamburg who have served as Senators of Hamburg! He is to court martial the five culprits among them and have them shot. ${ }^{34}$

On August 5, 1806, a letter was sent to Marshal Berthier. Napoleon gave directions for punishment that was to be dealt out to some German booksellers. He said:

I imagine that you have arrested the Angsburg and Nuremberg booksellers. My intention is to bring them before a court martial and to have them shot 
within twenty four hours. ${ }^{35}$

While fighting in Egypt in 1798, Napoleon, still striving for glory, gave orders as to what should be done to prisoners who were captured with weapons. There had been a revolt behind the lines and Napoleon wanted this matter handled swiftly and severely. He wrote to General Berthier:

Instruct the officers in command of the place to decapitate all prisoners taken with arms in their hands. They are to be taken to-night to the bank of the Nile between Boulag and Old Cairo: and their headless bodies are to be thrown into the river. ${ }^{36}$

All of the above are examples of the cruel measures meted out by Napoleon.

These actions were coldly calculated in order to best achieve his ultimate end. In his coldly, calculating manner Napoleon was not opposed to exhibiting severe discipline to his own men. Soon after he began his invasion of Italy, he wrote a letter to the Directory describing the actions that he took to quell looting amongst his own troops. In part the letter stated:

There is less looting... The wretches (i.e., the looters) are excusable: after languishing for three years on the crest of the Alps, they came into the promised land and wanted to taste its fruits. I had three of them shot and sent six more back to break stones beyond the Var. ${ }^{37}$

In this example, Napoleon stated that he found the looting excusable but he had men shot as an example anyway. To achieve glory in Italy, he had to maintain strict control of his troops.

Time and again in both primary and secondary sources, Napoleon makes clear his ultimate purpose, his lofty intent - the attainment of glory. He was not beyond cruel and severe actions to achieve these ends and yet there were moments that shed a light on a 
softer side of Napoleon. He never really wanted to fight Russia. Possibly, this feeling was fear or it might have been respect but needless to say he eventually invaded the huge expanse of land that was Russia in 1812. After Napoleon had occupied Moscow, it was burned (by the Russians not the French). Napoleon wrote a letter to Alexander I, Czar of Russia regarding the destruction of the city. In the letter Napoleon commented on the reasons for the invasion in the first place. He said, "I made war on Your Majesty without any hostile feelings. ${ }^{\prime 38}$ Even when he led six hundred thousand men into Russia bent on forcing her to join his continental system, he still liked and respected the Russian leader. War for Napoleon was not to be taken personally.

Finally, Napoleon could also offer rewards for a job well done, even if that task were performed by the enemy. On November 12,1811 , Napoleon was crossing the river at Givet. Some British prisoners were repairing a bridge. He noticed a group of about ten men who were distinguishing themselves through their efforts. He wrote a letter to General Clarke, Duke of Feltre, who was in command of this district. Napoleon said, "Order a list to be made of the ten men who distinguished themselves most in this affair: see that each of them is given a new suit of clothes, five Napoleons, and a passport for Morlaix, where they will be referred to the Transport Office, with an account of the reason for their liberation." 39

To accomplish his tasks, which would then bring about his ultimate end, Napoleon could order men to be shot, beheaded, thrown in the galley, or to be banished to the rock pile, but he could also reward for a job well done whether it be friend or foe. Reward was just as important for Napoleon in attaining his glory. 
Napoleon wanted glory more than anything else. As a leader he did not see situations differently at different times. In trying to achieve his ultimate end he felt that all actions had to be calculated by him and then instructions would have to be forwarded to his followers. Those actions could be harsh in certain situations or kind in others but what is key is that no matter what the situation, how it was to be addressed was decided upon by Napoleon. If his followers were always perceived as maintaining a low readiness level then this leadership style used on a day to day basis to achieve his ultimate end was appropriate. 


\section{CHAPTER IV NOTES}

${ }^{1}$ Andre Maurois, $\underline{\text { A History of France, }}$ trans. Henry L. Biorsse and Gerard Hopkins (New York: Farrar, Straus, and Cudahy, 1948), 267.

${ }^{2}$ Ibid., 267.

${ }^{3}$ Ibid., 271.

${ }^{4}$ Will and Ariel Durant, The Age of Napoleon (New York: Simon and Schuster, 1975), 95 .

${ }^{5}$ Louis Bergeron, France Under Napoleon, trans. R. R. Palmer (New Jersey: Princeton University Press, 1989), 70.

${ }^{6}$ Ibid., 38.

${ }^{7}$ Maurois, 190-110.

${ }^{8}$ Will and Ariel Durant, 262.

${ }^{9}$ Ibid., 262.

${ }^{10}$ Bergeron, 8 .

${ }^{11}$ Ibid., 8.

${ }^{12}$ Ibid., 8.

${ }^{13}$ Maurois, 333.

${ }^{14}$ Bergeron, 101.

${ }^{15}$ Mourois, 309.

${ }^{16}$ Ibid., 334. 
${ }^{17}$ Ibid., 336.

${ }^{18}$ R. Ernest Dupuy and Trevor N. Dupuy, The Harper Encyclopedia of Military History (New York: Harper Collins Publishers, Inc., 1993), 802.

${ }^{19}$ Ibid., 802.

${ }^{20}$ Ibid., 802.

${ }^{21}$ Ibid., 805.

${ }^{22}$ Ibid., 809.

${ }^{23}$ J. Christopher Herold, ed. and trans., The Mind of Napoleon (New York:

Columbia University Press, 1965), 120.

${ }^{24}$ Ibid., 163.

${ }^{25}$ Ibid., 167.

${ }^{26}$ J. M. Thompson, ed. and trans., Napoleon's Letters (London: Everyman's

Library, 1964), 125.

${ }^{27}$ Ibid., 163.

${ }^{28}$ Ibid., 139.

${ }^{29}$ Ibid., 223.

${ }^{30}$ Thompson, 80-81.

${ }^{31}$ Herold, 220.

${ }^{32}$ Ibid., 281.

33 Thompson, 52. 
${ }^{34}$ Ibid., 280.

${ }^{35}$ Ibid., 149.

${ }^{36}$ Ibid., 75.

${ }^{37}$ Herold, 213.

${ }^{38}$ Ibid., 274.

${ }^{39}$ Thompson, 260-261. 


\section{CHAPTER V}

\section{COMPARATIVE ANALYSIS}

The purpose of this comparative analysis is to clarify how Julius Caesar, Niccolo Machiavelli, and Napoleon Bonaparte did or did not embrace Hersey and Blanchard's Model of Situational Leadership and how their leadership style was affected by the ethics of the situation. The analysis will consist of the following factors: the historical context, primary sources utilized, whether the leader did or did not embrace characteristics of Hersey and Blanchard's Model of Situational Leadership, and how the ethics of the situation applied to each figure's leadership characteristics. In completing the comparative analysis, the following issues will be addressed:

1. Determine how the factors to be considered are similar.

2. Determine how the factors to be considered are different.

3. Based on this evidence, develop conclusions.

Finally, based on these conclusions, implications for educational leaders of today will be discussed.

SIMILARITIES

Even though each of the three leaders from the history of western civilization studied are from different historical eras, similarities to be considered can be found. In 
each of the three separate historical time frames, society was based on the ownership of property. In Ancient Rome, Florence of the Italian Renaissance, and Napoleonic France, the driving forces of society were based on land ownership. Property fostered influence in Rome, patronage in Florence, and the rise of the middle class in France. Within these societies the study and appreciation of art, philosophy, literature, etc. was encouraged. Each of the three geographical regions of the study were the Western European cultural centers of their respective eras.

Politically, the idea of the republic was a common denominator within the historical context of each of the three leaders studied. Caesar destroyed the Roman Republic when he crossed the Rubicon and began the Roman Civil War, Machiavelli lived in and wrote about the Republic of Florence, and Napoleon demolished the French Republic when he seized power in the coup detat of 1799. All three leaders were either a part of a republic or were instrumental in the destruction of a republic during their careers.

Militarily, all three leaders experienced the effects, both good and bad of standing, professional armies. With these professional forces each leader led or witnessed wars of conquest which raged across Western Europe.

Similarities can also be found in analyzing the primary source used in this research to determine whether or not Caesar, Machiavelli, and Napoleon embraced Hersey and Blanchard's Model of Situational Leadership. All of the primary sources found in this dissertation contain material either written or dictated by the leader of the 
era. There are likenesses when reviewing the author's expertise. Each of the leaders was a politician and at least a portion of their primary source material reflected political concerns. All three wrote about war, although not all were leaders of men in battle. Machiavelli wrote "The Art of War" which was a blueprint for military action although he never led the large numbers of men in battle as did Caesar and Napoleon. There is another common thread throughout, Caesar enhanced the military tactics as developed by his uncle Marius, Machiavelli rejuvenated Roman military tactics in his military treatise "The Art of War", and Napoleon studies Machiavelli's works as he stormed across Western Europe. Through this connection and similarity, the military tactics and thought of the ancients was carried through the ages from Caesar to Machiavelli and finally to Napoleon.

The purpose of this study was to determine whether or not Caesar, Machiavelli, and Napoleon embraced the leadership style as exemplified in Hersey and Blanchard's Model of Situational Leadership. In addition it was to be examined as to how the ethics of the situation affected the leader and the leadership style of that figure.

In examining the leadership style of these three historical figures, similarities are discovered. Caesar, Machiavelli, and Napoleon each had an ultimate goal or end which served as an ethical framework from which they made their decisions. Each applied the ethic of responsibility daily in order to achieve their ultimate goal.

Caesar's ethic of the ultimate end was the achievement of power. His constant thought was focused on what was necessary in order to achieve that ultimate end. On a 
day to day application of the ethics of the different situations, Caesar might send a whole population into slavery, destroy a town, or spare a foe who had fought honorably. He would do whatever was necessary to achieve his ultimate end - supreme power.

Machiavelli also operated from an ethic of an ultimate end. His ultimate goal was glory and honor. He looked to the ancients for guidance in achieving honor and glory. From an analysis of the ancients, he decided that to benefit the common good, which would lead to glory for himself, some had to suffer. Cruelty, at times, was necessary to gain glory and honor. On a day to day application, his ethic of responsibility could exhibit cruelty but always guided his actions towards that ultimate end - glory.

The attainment of glory was the ultimate intent of Napoleon Bonaparte. Glory was his ultimate ethic. The daily ethics of the situation, having people shot, decapitating rebels, or sending the sons of France to their deaths by the thousands, were all examples of Napoleon doing whatever was daily necessary in order to achieve his ultimate end glory.

\section{DIFFERENCES}

Within the historical context of each, differences are discovered. In analyzing the socio-economic context, it is found that the economies of Ancient Rome and Renaissance Florence were based on trade and Napoleonic France was based on agriculture. In addition, at the time of Caesar and Machiavelli, commerce was expanding and at the beginning of Napoleon's rise to power, trade in France was not.

Politically, in Caesar and Napoleon's eras, class struggle was a common 
denominator. In Caesar's time, the rich patrician's had been in a struggle for power with the rising plebeians. Prior to Napoleon coming to power, the French Revolution erupted partly because of a class struggle between the clergy and nobility of the First and Second Estate and the middle class of the Third Estate. In addition, both Caesar and Napoleon became dictators while Machiavelli remained a writer and politician trying to survive within the patronage system of Renaissance Italy.

Militarily, Ancient Rome and Napoleonic France could boast of the best generals in the world at that time and the most powerful armies. Through the application of their leadership and the prowess of their soldiers, Caesar and Napoleon conquered many foes. Machiavelli however, never had the opportunity to lead large bodies of men in conflict; nor did Renaissance Italy stand as the military power of the era.

The primary sources utilized are all from different eras. Caesar's ends in the 40's BC, Machiavelli's in the early 1500's, and Napoleon's in 1817.

The author's expertise of each is also slightly different. While each could claim to be politicians and their political writings came from that expertise, only Caesar and Napoleon could qualify as military practitioners. Their actions in the field far outweighed Machiavelli's military theories which were developed from his reading of the ancients.

When Caesar and Napoleon wrote the primary source material utilized in this study there was no evidence of special interest. They were not trying to win favor. However, Machiavelli, specifically in The Prince was trying to gain acceptance and influence with the powerful Medici Family - the rulers of the Florentine Republic. 
In the Model of Situational Leadership it is clearly stated that there is no best way for leaders to influence people. The effective leader, according to the model, should vary leadership styles depending on the readiness level of a group of followers to perform a specific task. There are differences in how Caesar, Machiavelli, and Napoleon applied leadership styles in attempting to influence behavior.

The leader, who embraces Hersey and Blanchard's Model of Situational Leadership, determines the readiness level of his followers when attempting to get them to complete a specific task. It is that leader's responsibility to move that group of followers through the various levels of readiness and get them to advance as far as they could go. Julius Caesar and Niccolo Machiavelli exhibited evidence of determining the readiness level of their followers. Caesar would determine the readiness level of his men and in fact if his objective were to attack a fortified town and his men weren't ready, he did not cause them to advance. He openly avoided battle if his men weren't ready.

Machiavelli also exhibited examples of analyzing the readiness level of followers. He stated that men needed to be inflamed to fight. In assessing the readiness level prior to battle he thought that it would be necessary to spur the men on. In other words it had to be determined where they were and how to move them to a readiness level which could be effective in battle.

Napoleon never tried to determine the readiness level of his troops. In all of the evidence examined, he exhibited a telling leadership style. He always felt that his men, even his closest confidants, were unable to grasp the grand design of his thinking. He not 
only failed to assess the readiness level of his followers but he also neglected to attempt to move them from one readiness level to another. He never wrote books on war such as Caesar and Machiavelli because he was a man of action but also because he did not want to commit his thoughts to paper. He did not want anyone, whether they be friend or foe to discover his key to success. He failed to prepare his troops and officers to take over responsibility. Napoleon neglected to transform his followers from an unwilling or unable level to able and willing.

Caesar, Machiavelli, and Napoleon all had an ultimate goal or end. This ultimate end was the ethic that formed the value system from which they based all of their decisions. Napoleon and Machiavelli sought glory and honor, while Caesar desired supreme power. While Machiavelli never really achieved power, Napoleon did - even though he really wanted glory.

\section{CONCLUSION}

Julius Caesar, Niccolo Machiavelli, and Napoleon Bonaparte were driven men. Each sought an ultimate end. With Napoleon and Machiavelli, glory formed an ultimate ethic, and with Caesar the ultimate purpose was the attainment of supreme power. As these leaders were confronted with different situations which called for different actions, they always seemed to function from the ethic of responsibility. They carefully calculated what the consequences of their decisions might be, always chasing that ultimate goal of power or glory.

The essence of situational leadership is applying an appropriate leadership style to 
each different situation. That situation or specific task will find the followers at different readiness levels. If the leader wants to be effective, according to the model, he must determine that readiness level and match the appropriate leadership style to the follower readiness level. All the while, the effective leader, in the model, attempts to move the readiness level of the followers from unable and unwilling to able, competent, willing, and confident.

Based on the evidence found within the primary sources utilized in this study, Julius Caesar and Niccolo Machiavelli can be deemed situational leaders. Evidence is found that illustrates that based on specific tasks both matched different leadership styles to different situations. Machiavelli's famous "Know when to be the fox or the lion", is a perfect example of the application of situational leadership, matching different styles to different situations. Under their leadership, specifically with Julius Caesar, followers were encouraged to take on more responsibility so that they could one day command on their own.

Napoleon Bonaparte rarely measured the readiness level of his followers. It appears that he did not ever want any of his followers to learn of his grand design or master strategy. If he did, he certainly did not apply a matching leadership style. Therefore, based on the evidence of the primary sources, Napoleon Bonaparte cannot be classified as a situational leader.

Leadership is built upon the ability of the leader to change the mindset, the framework of another person. Altering the framework of a person is influencing behavior. 
An effective leader adjusts the leadership style to the readiness level of the followers in attempting to complete a task. Measuring the readiness level of the followers to complete the task and then selecting an appropriate leadership style to that readiness level is influencing behavior effectively.

From this study we know that Julius Caesar, Niccolo Machiavelli, and Napoleon Bonaparte all influenced behavior. However, each did not embrace the leadership characteristics of Hersey and Blanchard's Model of Situational Leadership. Does this mean that only Caesar and Machiavelli were effective leaders and Napoleon was not? If effective leadership is simply influencing behavior then all three would be deemed effective. But if the definition of effective leadership is influencing behavior within a framework where the followers are also prepared for assuming responsibility and taking initiative when the leader is not present then Caesar, Machiavelli, and Napoleon were not all effective. Caesar and Machiavelli were preparing followers for leadership, Napoleon dared not ever share his secrets. A component of Hersey and Blanchard's model is the leader attempting to move the followers through the readiness level continuum. Caesar and Machiavelli did this but Napoleon did not. Napoleon definitely influenced the behavior of his followers but did not prepare them for his absence. Therefore, using this definition of effective leadership Julius Caesar and Niccolo Machiavelli were effective leaders while Napoleon Bonaparte was not. They were all leaders and influenced the behavior of their followers or readers but only Caesar and Machiavelli were effective because they prepared their followers for future responsibilities by measuring their 
readiness level and through providing more responsibility to the followers, moved them through the various levels of readiness.

Effective leadership is a balance. There is a balance between influencing the behavior of the followers through leadership and providing the followers with leadership responsibilities themselves. There is a balance between the task and relationship behavior of the leaders as compared to the readiness level of the followers. Finally, in effective leadership there is a balance between an ultimate goal and the daily application of leadership to achieve that goal.

Julius Caesar, Niccolo Machiavelli, and Napoleon Bonaparte influenced the behavior of many. Caesar and Machiavelli embraced Hersey and Blanchard's Model of Situational Leadership in influencing the behavior of others and preparing followers for leadership. Napoleon influenced the behavior of others but he did not project an effective model because he did not provide for the future.

\section{IMPLICATIONS FOR EDUCATIONAL LEADERS TODAY}

This study analyzed three men from the history of Western Civilization in order to determine if there was a relationship between their leadership styles and Hersey and Blanchard's Model of Situational Leadership. Weber's two ethics was used as an additional lens to examine the leadership of these figures. Caesar and Machiavelli closely resemble the model and Napoleon does not.

Caesar, Machiavelli, and Napoleon were leaders in the military/political arena. Can the lessons learned from analyzing their leadership style have any implications for 
leaders in education today?

To determine if there are implications for educational leaders today from these lessons of the past, an analysis will be made of case studies from Hoy and Tarter's Administrators Solving the Problems of Practice and Kirschmann's Educational Administration A Collection of Case Studies depicting leadership actions of both superintendents and principals. From these case studies it will be determined whether the educational leaders embrace or reject Hersey and Blanchard's Model of Situational Leadership. In addition, the case studies will also be viewed through the lens of Weber's two ethics.

Effective leadership is influencing behavior. Based on Hersey and Blanchard's Model of Situational Leadership this influence is demonstrated by matching an appropriate leadership style to a readiness level of the followers. In addition, according to Weber's two ethics, the daily application of leadership is calculated in order to achieve an ultimate end. That daily application can be the utilization of Hersey and Blanchard's Model. Caesar and Machiavelli were effective leaders because they both had ultimate ends. They influenced behavior through the daily application of what we now define as Hersey and Blanchard's Model of Situational Leadership. They calculated what leadership style to utilize in order to achieve that ultimate end.

Do educational leaders today exhibit these same characteristics and if so are they considered effective leaders? To examine this question, two administrative case study books noted above were analyzed. The books included decisions from both the principal's 
and superintendent's perspective. Educational leaders today will find case studies, similar to the case studies analyzed in this study, useful as models from which the daily application of leadership decision-making may be based.

\section{SUPERINTENDENT/PRINCIPAL CASE STUDIES}

\section{SITUATION A - Administrators Solving the Problems of Practice}

\section{DESCRIPTION OF THE CASE}

Superintendent Edison established a teacher's council elected by teacherrepresentatives of every public school in a large industrial city. She regularly consulted with teachers in an effort to create a democratic school system.

Dr. Edison, after six years of service, wanted to build a teacher's council as a vehicle of communicating with rank-and-file teachers. This was an attempt to construct a direct connection with teachers in order to assess their reactions to her policies. She promised the 8,000 member teacher's union that this was not an attempt to usurp their power.

The union discovered that questions of teacher's welfare were raised at the meetings of this council and they reacted as this were an attempt to wrest power from their position. The union and Dr. Edison were at odds because she needed a sounding board in a large school district and the union, while liking Dr. Edison's leadership style, did not want to lose any power by allowing this council to discuss contract issues. DR. EDISON AS A SITUATIONAL LEADER

Dr. Edison is described as a superintendent who prefers a democratic school 
system. "It is true that teacher suggestions were not always adopted, but enough were accepted to give teachers both individually and collectively the feeling that their superintendent meant what she said in the matter of wanting a democratic school system." In this specific situation, she asked each building in her district to elect a representative to the council to serve on the teacher council. This is an example of an (S3) participating leadership style. The readiness level of the followers, the teaching staff, which includes council members, is a an (R3) able but unwilling or insecure readiness level. The staff likes the superintendent and the way she operates but some, particularly union members, are insecure about the purpose of this council. This insecurity was based on past superintendent actions and not Dr. Edison.

Based on the readiness level of the followers for the specific task, Dr. Edison applied the appropriate leadership style (See Figure 4). She matched a participating style of leadership where teachers could share ideas with her to a group of followers who were able but insecure.

\section{THE ETHICS OF THE SITUATION}

Based on the evidence presented in this case study, Dr. Edison's ultimate intent was to have a democratic school system where all constituencies would have a share in decision making. The development of the teachers council was an example of applying a leadership style on a daily basis to achieve that end.

SITUATION B - Administrators Solving the Problems of Practice 


\section{CASE STUDIES}

\section{EDUCATION LEADERS TODAY}

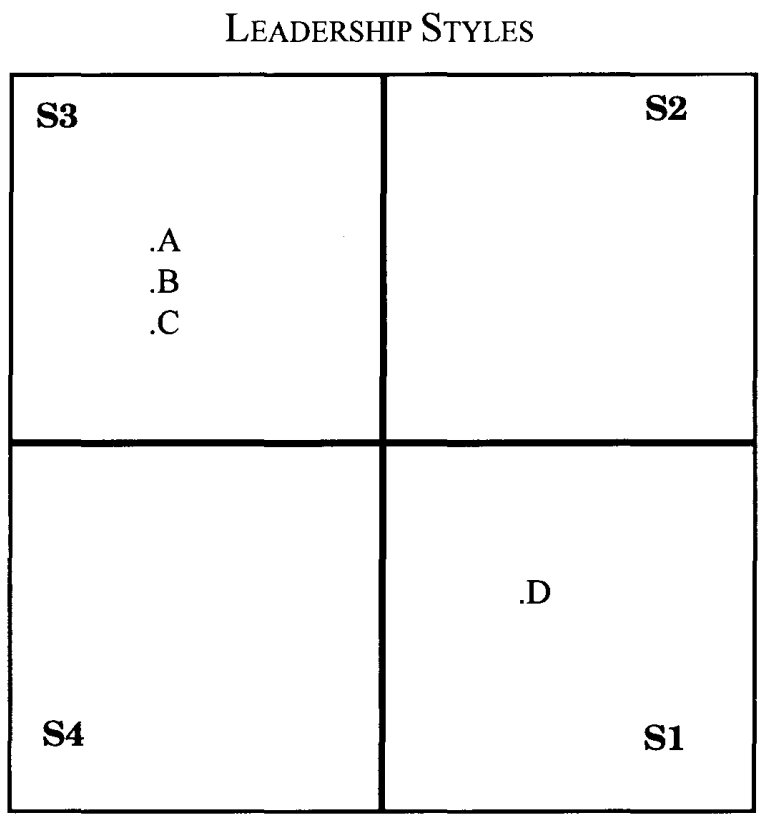

READINESS LEVEL OF FOLLOWERS

\begin{tabular}{l|l|l|l}
$\mathbf{R 4}$ & $\mathbf{R 3}$ & $\mathbf{R 2}$ & $\mathbf{R 1}$ \\
\hline & .A & & .D \\
& .B & & \\
& .C & &
\end{tabular}

Situation $\mathrm{A}=. \mathrm{A} \quad$ Dr. Edison, Teacher Council

(S3 - R3)

Situation $\mathrm{B}=. \mathrm{B}$

Dr. Frank, Sex Education

(S3 - R3)

Situation $\mathrm{C}=. \mathrm{C}$

High School Principal, Rotate Lunch

(S3 - R3)

Situation $\mathrm{D}=. \mathrm{D}$

Samantha, 3rd Grader

Figure 4 
Dr. Charles Frank, the Superintendent of Schools in Marshall Creek was the product of the local school system. He grew up there, became a teacher in the school system, the high school principal, and eventually superintendent. Dr. Frank understood the politics of the community and the concerns of the newcomers in the rapidly changing community.

The PTO was also changing. It had at one time been a strong support for the conservative values of the old community but now it had a militant group made up of newcomers to the community.

A recent high school PTO meeting focused on sex education. The militant faction of the PTO had wanted a comprehensive program that began in first grade and included such topics as contraceptives, safe sex, and abortion. A proposal to distribute condoms had polarized both the community and the staff.

The high school principal contacted Dr. Frank after the latest PTO meeting to inform him of the proceedings. Dr. Frank knew that although the matter of sex education was controversial, it had to be confronted. However, he wanted to study the issue in order to make a rational decision.

A fight occurred at the high school between two boys. One boy was HIV positive. Rumors spread rapidly through the school and the community regarding this incident and AIDS.

A group of parents, led by a school board member, insisted that all teachers and students be tested immediately and that any student found to have HIV should be 
removed immediately. If these demands weren't met immediately, the group threatened to boycott the school.

The state said that they would enforce all attendance requirements in this case. Dr. Frank sat back in his chair and reflected as to what he should do next.

\section{DR. FRANK AS A SITUATIONAL LEADER}

Dr. Frank had a specific task which was to construct a comprehensive sex education program but he had a potential crisis, the boycotting of school, as a result of the HIV student incident. Dr. Frank has a leadership decision to make. Who are his followers in this specific task? He must lead the board members and the staff in this situation. The task had now become to build a comprehensive program in light of the possible boycotting.

Dr. Frank had various levels of follower readiness. "Most people are violently opposed to a sex education program that goes beyond basic health and reproductive issues, taught in the high school." ${ }^{, 2}$ This group of followers would be labeled (R1) unable and or unwilling. He also had the newcomers who vehemently wanted a more comprehensive program. They would be labeled (R4) able and willing.

When taken as a whole the followers could be defined as (R3) able but unwilling or insecure. They could accept a comprehensive program but some could embrace it totally while others might not.

Prior to the HIV incident, Dr. Frank intended to exhibit an (S3) leadership style. "He decided to mobilize a study team comprised of parents, teachers, students, social 
workers, and medical authorities to prepare a report on which he could base his actions."3 The fight between the boys and the subsequent community uproar put this action on hold. The case study ended with Dr. Frank reflecting as to what his next move should be.

Before this crisis, Dr. Frank exhibited an appropriate match between an (S3) leadership style and (R3) readiness level (See Figure 4).

\section{THE ETHICS OF THE SITUATION}

Dr. Frank's ultimate end is to address the concerns of the more aggressive newcomers while still holding to the conservative values of the old community. Unfortunately, Dr. Frank will have to decide upon one or the other because balancing between both camps is not holding to Weber's ethic of the ultimate end. He's simply trying to survive with no proactive plan in place.

Dr. Frank is caught in a transition. As the Newcomers continue to move into the community, dissonance over issues will continue to become issues. He must define a stance so that the daily application of leadership has an end in mind.

\section{SITUATION C - $\underline{\text { Administrators Solving the Problems of Practice }}$}

\section{DESCRIPTION OF THE CASE}

Mile Run is a relatively small Midwestern community. The new high school principal has been asked by the superintendent to end the traditional practices of the old principal and move forward in a more progressive manner.

Five ninth and tenth graders came to his office to complain about lunch. Their concern was that by the time freshmen and sophomores eat, all of the good food was 
gone. The principal told the students that he would meet with them on Wednesday to discuss a solution. He met with the assistant principal and the head of the cafeteria. The assistant principal said that the system of lunch periods was established years ago and the head of the cafeteria agreed that many times most of the good food was gone by the end of lunch.

To be fair the new principal decided to rotate the period that the seniors, juniors, sophomores, and freshmen would eat. The suggestion actually came from the assistant principal. The student group was pleased. Soon however, the seniors began to boycott lunch because they did not want to ever eat last. Soon all of the seniors were part of the boycott and it was spreading to the juniors as well.

\section{THE PRINCIPAL AS A SITUATIONAL LEADER}

The principal gathered input when confronted by the five students with the lunch period concern. The specific task was to create a progressive yet equitable system of eating lunch. The principal shared ideas with his followers, the assistant principal, the head of the cafeteria, and the group of students. This exemplified an (S3) participating style of leadership. This style appropriately matched with an (R3) able but unwilling or insecure follower readiness level (See Figure 4). The head of the cafeteria and the assistant principal liked the rotating idea. "The students are pleased by the remarks." However, soon some of the seniors began to boycott lunch, thus demonstrating able but unwilling follower readiness.

The principal determined that the followers, including staff and students, were 
able but unwilling or insecure to rotate lunch as a whole. Therefore, he gathered input from staff and students. Unfortunately, based on the evidence found in the case study, it doesn't appear that he gathered enough information from the seniors.

\section{THE ETHICS OF THE SITUATION}

The principal's ultimate end is to end the traditional practices of the past and implement more progressive decisions throughout the high school. The daily application of leadership necessitated that he make a decision regarding the lunch periods. His decision was an example of participatory leadership appropriately matched to that level of follower readiness. However he did not get a complete cross section of the thoughts of all followers regarding the issue.

\section{SITUATION D - Educational Administration A Collection of Case Studies}

\section{DESCRIPTION OF THE CASE}

Samantha is a tough, wiry third grader in Ms. Johnson's class. Samantha had shoved Larry out of the lunch line and took his place. When Larry protested, Samantha threatened to fight. Ms. Johnson brought Samantha into the principal's office and said that she had it with Samantha and her pushy mother. The principal called the mother in.

When the mother arrived, she immediately let the principal know that she was dissatisfied with having to leave work for this matter. In fact she admitted that she was proud of her daughter's actions. The mother suggested that the principal keep his nose out of how she raised her daughter. 


\section{THE PRINCIPAL AS A SITUATIONAL LEADER}

The specific task was to address the disruptive behavior of a third grade student. The followers in this case are the teacher and the mother.

The followers exhibited an (R1) readiness level. "Ms. Johnson pulled her out of line and brought her to your office." ${ }^{, 5}$ She wanted the principal to do something about Samantha, she did not want to deal with the issue. The mother told the principal to keep his nose out of her business. Clearly these followers were unwilling to alter the behavior of this child.

The principal appropriately applied an (S1) telling leadership style. "You say that Samantha was clearly the antagonist in this situation." The principal describes the girl's actions to the mother and tells her that they will stop (See Figure 4).

\section{THE ETHICS OF THE SITUATION}

The principal's ultimate end, as evidenced by the case study, is to have a well run school where students behave. By addressing the concerns of the teacher with the parent, exhibiting a telling form of leadership style, the principal is applying daily leadership characteristics to achieve an ultimate end.

COMPARISON OF JULIUS CAESAR, NICCOLO MACHIAVELLI, AND

\section{NAPOLEON BONAPARTE TO EDUCATIONAL LEADERS OF TODAY}

How do the educational leaders of today examined in the above case studies relate to Julius Caesar, Niccolo Machiavelli, and Napoleon Bonaparte? To determine this, a comparative analysis examining the similarities and differences between the educational 
leaders and the leaders of the past will be completed.

\section{SIMILARITIES}

None of the leaders of the past exhibited the (S2)

selling form of leadership style. The case studies analyzed did not exhibit the (S2) Selling leadership style either. Does this mean that effective leadership, whether on the battlefield or in the school does not exhibit selling? Based on the evidence gathered in this study it would seem that effective leadership does not include a selling form of leadership.

The leadership style of leaders from the past and the educational leaders of today appeared in more than one quadrant of Hersey and Blanchard's Model. The educational leader's styles were in quadrant (S1) and (S3) and the quadrants exhibited by the leaders from the past were (S1), (S3), and (S4).

\section{DIFFERENCES}

the majority of the leadership styles exhibited by the figures from the past were found in the (S1) telling form of leadership. The majority of the leadership characteristics evidenced by educational leaders of today, contained in the case studies compiled in Administrators Solving the Problems of Practice and Educational Administration A Collection of Case Studies, were found in the (S3) participating leadership style quadrant. None of the educational leaders exhibited an (S4) delegating style of leadership, while two leaders from the past exhibited an (S4) delegating leadership style.

What does this mean? Two leaders from the past were military men and found themselves in many situations where direct and precise orders had to be given in order to 
achieve objectives. At times these decisions were made when time was of the essence.

Today's educational leaders did not face this constraint in most of the leadership situations analyzed. In the educational climate of today, leadership is still defined as influencing behavior but this influence is to be displayed in a democratic fashion where followers are to become part of the process. Gone are the days of top down, autocratic leadership.

Educational leaders of today need and want to influence behavior of their followers. They must have an ultimate end, a goal, a set of principles upon which to base their decisions. Stephen Covey States, "Leadership derives its power from values and correct principles." ${ }^{7}$ This power to influence followers, to change behavior must come from an ultimate end, a set of principles and values. Effective leaders maintain this vision, Weber's ethic of ultimate ends. Effective educational leaders today, by applying Hersey and Blanchard's Model of Situational Leadership, exhibit Weber's ethic of responsibility. Educational leaders today are practical, opportunistic, and self-serving. They exhibit all three of these characteristics by identifying specific tasks, measuring their followers readiness level to complete this task, matching an appropriate leadership style, and moving their followers through the readiness level continuum at appropriate times. These daily applications of leadership, the ethic of responsibility, all fall under that ultimate vision.

The effective leadership of Julius Caesar and Niccolo Machiavelli had all of these characteristics. These leaders had an ultimate goal and daily applied measures and 
leadership styles to achieve their goal. They were practical, opportunistic, and selfserving in their daily application of leadership.

Using Caesar and Machiavelli as a lens to view lessons from the past, educational leaders of today can also see that in order to be effective they too must define an ultimate end and daily apply leadership characteristics to achieve this end. To be effective, leaders of today must constantly measure the readiness level of their followers in order to achieve specific tasks which are part of an ultimate end. Hersey and Blanchard's Model of Situational Leadership is a practical representation of the ethic of responsibility which can be applied in order to make decisions to influence and change behavior in the education arena today. 


\section{CHAPTER V NOTES}

${ }^{1}$ Wayne K. Hoy and C. John Tarter, $\underline{\text { Administrators Solving the Problems of }}$ Practice (Needham, Massachusetts: Paramount Publishing, 1995), 20.

${ }^{2}$ Ibid., 55 .

${ }^{3}$ Ibid., 56 .

${ }^{4}$ Ibid., 94 .

${ }^{5}$ Robert E. Kirschmann, Educational Administration A Collection of Case Studies (Englewood Cliffs, New Jersey: Merrill Prentice Hall, 1996), 11.

${ }^{6}$ Ibid., 11.

${ }^{7}$ Stephen R. Covey, Principle-Centered Leadership (New York: Simon and Schuster, 1991), 246. 


\section{Appendix A}

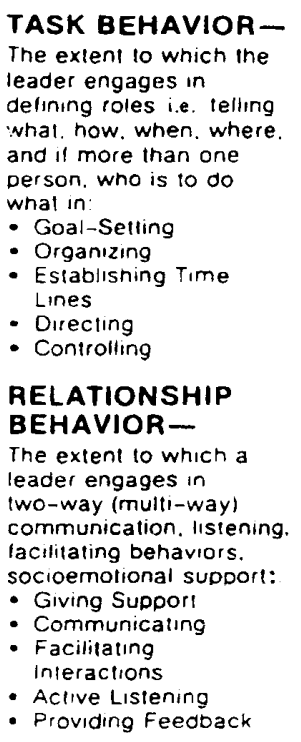

\section{LEADER BEHAVIOR}

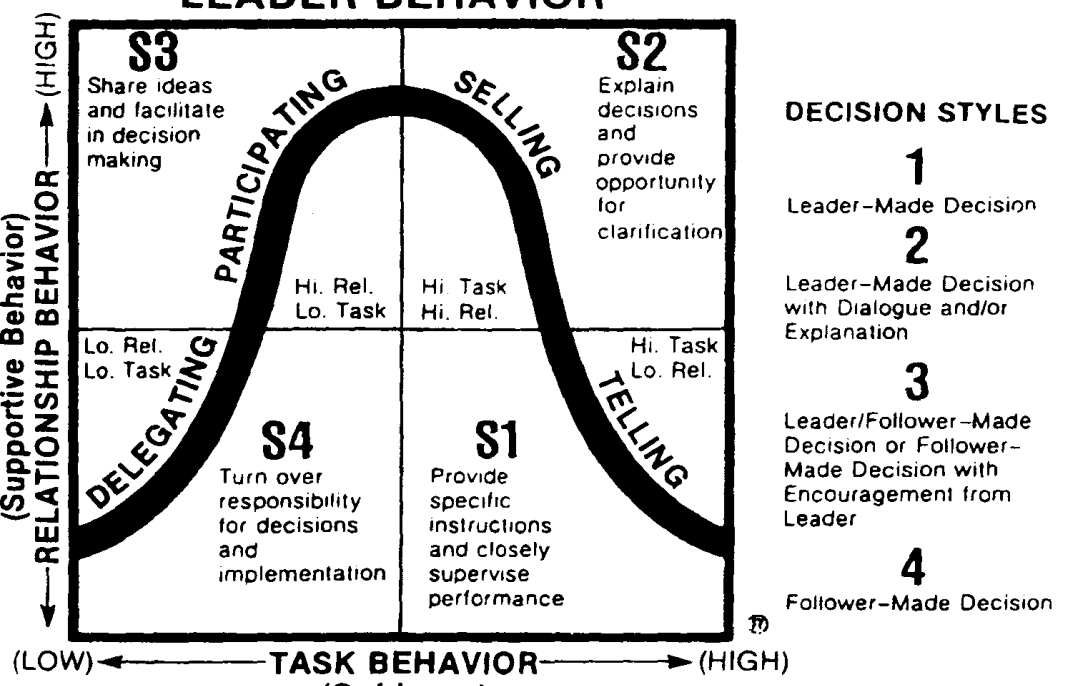

(Guidance)

\begin{tabular}{|c|c|c|c|}
\hline \multicolumn{4}{|c|}{ FOLLOWER READINESS } \\
\hline $\mathrm{HIGH}$ & $M O D$ & RATE & LOW \\
\hline R4 & R3 & R2 & $\mathbf{R 1}$ \\
\hline $\begin{array}{l}\text { Able and } \\
\text { Willing } \\
\text { or } \\
\text { Confident }\end{array}$ & $\begin{array}{l}\text { Able but } \\
\text { Unwilling } \\
\text { or } \\
\text { Insecure }\end{array}$ & $\begin{array}{l}\text { Unable but } \\
\text { Willing } \\
\text { or } \\
\text { Contident }\end{array}$ & $\begin{array}{l}\text { Unable and } \\
\text { Unwilling } \\
\text { or } \\
\text { Insecure }\end{array}$ \\
\hline $\begin{array}{ll}\text { FOL } \\
\text { DIR }\end{array}$ & $\begin{array}{l}E R \\
E D\end{array}$ & LE & $\begin{array}{l}\text { DER } \\
\text { TTED }\end{array}$ \\
\hline
\end{tabular}

ABILITY: has the necessary knowledge. experience and skill

WILLINGNESS: has the necessary confidence. commilment. motivation

When a Leader Behavior is used appropriately with its corresponding level of readiness, it is termed a High Probability Match. The following are descriptors that can be useful when using Situational Leadership for specific applications:

S1

Telling

Guiding

Directing

Establishing
S2

Selling

Explaining

Clarifying

Persuading
S3

Participating

Encouraging

Collaborating

Committing
54

Delegating

Observing

Monitoring

Fulfilling

Source: Hersey, Paul and Kenneth H. Blanchard, Management of OrganizationalBehavior, Englewood Cliffs, N. J., Prentice Hall, 1993, p 197. 


\section{SELECTED BIBLIOGRAPHY}

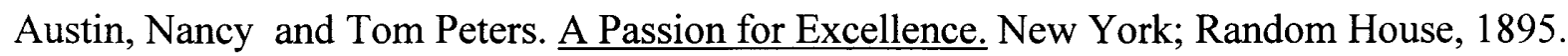

Balsdon, J.P.V.D. Julius Caesar: A Political Biography. New York: Atheneun, 1967.

Barrows, R.H. The Romans. Chicago: Penguin Books, 1949.

Bennis, Warren. On Becoming a Leader. Reading, Massachusetts; Addison-Wesley Publishing Company, Inc., 1989.

Bennis, Warren. Why Leaders Can't Lead. San Francisco; Jossey-Bass Publishers, 1989.

Bergeron, Louis. France Under Napoleon, trans. R. R. Palmer (New Jersey: Princeton University Press, 1981.

Blanchard, Kenneth H. and Paul Hersey. Management of Organizational Behavior. England Cliffs, N. J.; Prentice Hall, 1993.

Boak, Arthur E. and William G. Sinnigen. A History of Rome 753 BC to 565 AD. New York MacMillan Co., 1968.

Burns, James MacGregor. Leadership. New York; Harper Torchbooks, 1987.

Caesar, Julius. War Commentaries of Julius Caesar. New York: Amereon, Ltd., 1976.

Covey, Stephen R. Principle-Centered Leadership. New York: Simon and Schuster, 1991.

Dupuy, R. Ernest and Trevor N. Dupuy. The Harper Encyclopedia of Military History. New York: Harper Collins Publishers, 1993. 
Dupuy, Trevor N. and R. Ernest Dupuy. The Harper Encyclopedia of Military History. New York: Harper Collins Publishers, 1993.

Durant, Will and Ariel. The Age of Napoleon. New York: Simon and Schuster, 1975.

Ergang, Robert. The Renaissance. New York: D. Van Nostrand and Co., Inc., 1967.

Fuller, J.F.C. Julius Caesar. New Jersey: Rutgers University Press, 1965.

Grant, Michael. History of Rome. New York: Charles Scribner's sons, 1979.

Griffith, Francis. Administrative Theory in Education: Text and Readings. Midland, Michigan; Pendell Publishing Company, 1979.

Hale, John. The Civilization of Europe in the Renaissance. New York: Atheneum, 1994.

Herold, J. Christopher, ed. and trans. The Mind of Napoleon. New York: Columbia University Press, 1965.

Hersey, Paul and Kenneth H. Blanchard. Management of Organizational Behavior. England Cliffs, N. J.; Prentice Hall, 1993.

Hoy, Wayne K. and C. John Tarter. Administrators Solving the Problems of Practice. Needham, Massachusetts: Paramount Publishing, 1995.

Kahn, Arthur D. The Education of Julius Caesar. New York: Schocken Books, 1986.

Kirschmann, Robert E. Educational Administration A Collection of Case Studies. Englewood Cliffs, New Jersey: Merrill Prentice Hall, 1996.

Machiavelli, Niccolo. The Art of War. Trans. Ellis Farneworth, with a foreword by Neal Wood. New York: De Capo Press, Inc., 1965. . The Discourses. Ed. and with a Foreword by Bernard Crick. New York: Penguin 
Books, 1983.

. The Prince. Trans. W. K. Marriott. Chicago: Encyclopedia Brittanica, Inc., 1952.

Maurois, Andre. A History of France. Trans. Henry L. Biorsse and Gerard Hopkins. New

York: Farrar, Straus, and Cudahy, 1948.

Naphtali, Lewis and Meyer Reinhold. Roman Civilization. New York: Columbia University Press, 1967.

Payne, Robert. Ed. William Harlan Hale. The Horizon Book of Ancient Rome. New York: American Heritage, 1966.

Peters, Tom and Nancy Austin, A Passion for Excellence. New York; Random House, 1895.

Plutarch, Lives of Thermistocles, Pericles, Aristid Alcibades and Cariolanus, Demosthenes and Cicero, Caesar and Anthony, trans. Arthur Hugh Clough. New York: P. F. Collier and son, 1909.

Reinhold, Meyer, and Lewis Naphtali. Roman Civilization. New York: Columbia University Press, 1967.

Sinnigen, William G. and Arthur E. Boak. A History of Rome, $753 \mathrm{BC}$ to $565 \mathrm{AD}$. New York: MacMillan Co., 1968.

Strauss, Leo. Thoughts on Machiavelli. Chicago: The University of Chicago Press, 1984.

Sun-Tzu, The Art of War. Reinterpreted by J. H. Huang, New York: Quill William Morrow, 1993.

Tarter, C. John and Wayne K. Hoy. Administrators Solving the Problems of Practice. Needham, Massachusetts: Paramount Publishing, 1995. 
Thompson, J. M. Ed. and trans. Napoleon's Letters. London: Everyman's Library, 1964.

Weber, Max. Politics as a Vocation. Trans. H. H. Gerth and C. Wright Mills. Philadelphia; Fortress Press, 1965. . Economy and Society. Ed. Guenther Roth and Claus Wittich. New York: Bedminster Press, 1968. 


\section{VITA}

Kelly Dale Baird was born June 10, 1957, in Danville, Illinois.

A graduate of Addison Trail High School, Addison, Illinois, in 1975, Mr. Baird attended Augustana College, Rock Island, Illinois, where he completed the bachelor of arts degree in 1979. Mr. Baird completed a master of arts degree from Northeastern Illinois University, Chicago, in 1988. He attended Loyola University of Chicago, where he received a doctor of philosophy degree in 1996.

After completing nine years of classroom teaching in the public schools of the state of Illinois, Mr. Baird served as an elementary school principal from 1989 to 1994 . He has been a central office administrator from 1994 to the present.

Mr. Baird is married to Debra Baird, and is the father of three sons, Tom, age fifteen, Mike, age eleven, and Jeff, age five. 
DISSERTATION APPROVAL SHEET

The dissertation submitted by Kelly Dale Baird has been read and approved by the following committee:

Janis Fine, Ph.D. Director

Assistant Professor, Educational Leadership and Policy Studies

Loyola University Chicago

Gerald L. Gutek, Ph.D.

Professor, Educational Leadership and Policy Studies and History Loyola University Chicago

Max A. Bailey, Ed.D. and J.D.

Professor, Educational Leadership and Policy Studies

Loyola University Chicago

The final copies have been examined by the director of the dissertation and the signature which appears below verifies the fact that any necessary changes have been incorporated and that the dissertation is now given final approval by the committee with reference to content and form.

The dissertation is, therefore, accepted in partial fulfillment of the requirements for the degree of PhD
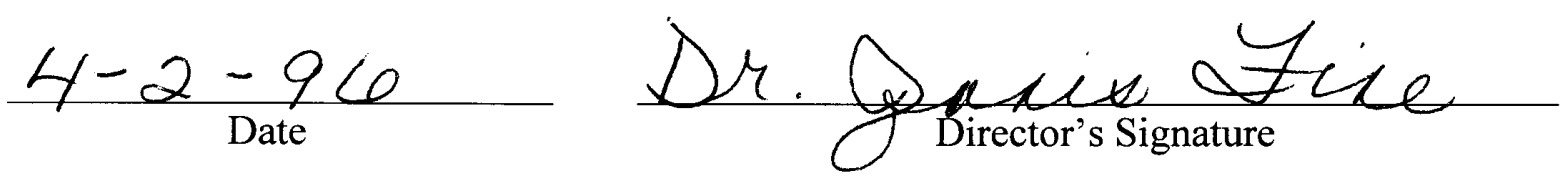